\title{
Nonconventional Weed Management Strategies for Modern Agriculture
}

\author{
Ali A. Bajwa, Gulshan Mahajan, and Bhagirath S. Chauhan*
}

\begin{abstract}
Weeds are a significant problem in crop production and their management in modern agriculture is crucial to avoid yield losses and ensure food security. Intensive agricultural practices, changing climate, and natural disasters affect weed dynamics and that requires a change in weed management protocols. The existing manual control options are no longer viable because of labor shortages; chemical control options are limited by ecodegradation, health hazards, and development of herbicide resistance in weeds. We are therefore reviewing some potential nonconventional weed management strategies for modern agriculture that are viable, feasible, and efficient. Improvement in tillage regimes has long been identified as an impressive weed-control measure. Harvest weed seed control and seed predation have been shown as potential tools for reducing weed emergence and seed bank reserves. Development in the field of allelopathy for weed management has led to new techniques for weed control. The remarkable role of biotechnological advancements in developing herbicide-resistant crops, bioherbicides, and harnessing the allelopathic potential of crops is also worth mentioning in a modern weed management program. Thermal weed management has also been observed as a useful technique, especially under conservation agriculture systems. Last, precision weed management has been elaborated with sufficient details. The role of remote sensing, modeling, and robotics as an integral part of precision weed management has been highlighted in a realistic manner. All these strategies are viable for today's agriculture; however, site-specific selection and the use of right combinations will be the key to success. No single strategy is perfect, and therefore an integrated approach may provide better results. Future research is needed to explore the potential of these strategies and to optimize them on technological and cultural bases. The adoption of such methods may improve the efficiency of cropping systems under sustainable and conservation practices.
\end{abstract}

Key words: Allelopathy, biotechnology, crop nutrition, herbicide resistance, precision agriculture, weed management.

Population explosion during the last few decades has exerted immense pressure on crop production, forcing the farming community to intensify agriculture to meet food demands. Weeds are a major factor causing reduction in crop yields through competition and allelopathic interactions. In modern-day agriculture, weed infestations and weed behaviors frequently change because of intensive management practices, climate change, and ecological shift (Chauhan et al. 2006, 2014). As a consequence, the existing management options need to be altered to ensure effective control given these shifts. In developing countries, manual or mechanical weed management is more prevalent, whereas in developed and technologically advanced regions, chemical weed management is dominant

\footnotetext{
DOI: 10.1614/WS-D-15-00064.1

* Research Higher Degree Scholar, School of Agriculture and Food Sciences, The University of Queensland, Gatton, Queensland 4343, Australia; Agronomist, Punjab Agricultural University, Ludhiana 141004, India; Principal Research Fellow, The Centre for Plant Science, Queensland Alliance for Agriculture and Food Innovation (QAAFI), The University of Queensland, Toowoomba, Queensland 4350, Australia. Corresponding author's E-mail: b.chauhan@uq.edu.au.
}

(Chauhan 2012; Chauhan and Gill 2014). The difference in management practices depends on labor and resource availability (Zimdahl 2013). Today's agriculture requires a modified weed management regime to cope with the problems associated with traditional techniques (Bajwa 2014). Ecology-based and nonconventional weed management tools may offer solutions to aggravating problems of herbicide resistance, environmental pollution, weed diversification, biological invasion, and yield losses (Chauhan 2013; Chauhan and Johnson 2010; Chauhan et al. 2010; Singh 2007). Keeping in view these problems and potential opportunities, nonconventional and nonchemical weed management strategies like improved tillage, crop nutrient management, weed seed predation, allelopathy, herbicide-tolerant crops, bioherbicides, thermal techniques, and precision weed management have been discussed comprehensively in this review.

The importance of modified tillage in weed management has been reviewed by several researchers (Bajwa 2014; Brainard et al. 2013; Chauhan et al. 2012; Chauhan and Gill 2014). Walsh et al. (2013) comprehensively reviewed the weed man- 
agement potential of harvest weed seed control. Their key recommendations have been highlighted in this review and the missing links have been elaborated. Impact of fertilizer management on weed dynamics is a relatively neglected aspect (Bajwa et al. 2014; Blackshaw and Brandt 2008), but this review provides an insight into this subject. Some classic reviews on the role of allelopathy in weed management have been published over the years (Bhadoria 2011; Cheema et al. 2013; Farooq et al. 2011, 2013; Nawaz et al. 2014; Weston and Duke 2003; Worthington and Reberg-Horton 2013). The practical implications, latest scenario, future research needs, and the scope of allelopathy in integrated weed management strategies have been thoroughly discussed in this review. Different reviews have concluded that the development of herbicide-tolerant crops has revolutionized the crop production in many regions (Beckie et al. 2006; Dill et al. 2008; Duke and Powles 2009; Green 2012). Although biological weed management is not a panacea under prevailing conditions, it has a great potential (Ash 2010; Charudattan 2001, 2005; Hallett 2005). Meanwhile, the advancements in technology have created vast opportunities for weed management in the form of thermal techniques, including flaming, solarization, electrocution, and microwave technology (Bond and Grundy 2001; Knežević et al. 2011; Rask and Kristofferson 2007). Precision weed management is another prospect of modern weed management. The application of remote sensing, modeling, and robotics in a very sophisticated and highly scientific manner (Christensen et al. 2009; Freckleton and Stephens 2009; Lamb and Brown 2001; Slaughter et al. 2008; Thorp and Tian 2004; Torres-Sanchez et al. 2013; Young et al. 2014) will enable us to pave/tread excellent paths for a site-specific, efficient, targeted, and economical weed management in the future.

No doubt, each and every weed control strategy has some unique benefits, but under the current agriculture scenario, an overall shift toward more sustainable and targeted practices is inevitable. In this review, a detailed and comprehensive analysis of these potential strategies has been done, which will help weed scientists to view the comparative efficacies and potential implications of these alternative nonconventional strategies, primarily avoiding use of the synthetic chemicals. To the best of our knowledge, a comprehensive review of all these potential nonconventional weed management strategies leading to a fruitful effort for integrated weed management under the present and future conditions on a sustainable basis has not been presented previously.

\section{Improved and Targeted Tillage}

Tillage plays an important role in weed control and has been used as an effective management tool since ancient times. Tillage is still very effective, as different types of modern cultivators and weeders are facilitating mechanical weed management (Wallace and Bellinder 1992). The advent and successful adoption of no-till systems using herbicides have shown that tillage is not as necessary for crop production as it is for weed control (Zimdahl 2013). Tillage has significant impact on the efficiency of soil-applied herbicides, particularly dinitroanilines (Singh et al. 2012); higher water volume is required to improve the efficacy of PRE herbicides under zero-tillage systems (Borger et al. 2013).

\section{Tillage Implements for Weed Management.} Appropriate tillage implements are needed for an effective weed control. In ancient times, bullocks/ horses were used to move different types of cultivators, sweeps, and hoes for weed eradication. Since the advent of mechanized farming, the trend of using tractor-mounted equipment has increased. Tractor-mounted equipment is easier to use under conventional tillage systems but more difficult in modified tillage systems, including no-till, strip tillage, and other conservation tillage systems because of retained residues (Brainard et al. 2013). Residue mulches or living cover crops can be managed through mowing or use of a highresidue cultivator (Creamer and Dabney 2002). Some important mechanical weed-management tools include the use of a rotary hoe, rototiller, rotavator, power tiller, rod weeder, cultipacker, spring tine harrow, finger weeder, torsion weeder, brush weeder, spike-tooth weeder, and pneumatic weed blower (Duerinckx et al. 2005; Mohler et al. 1997). Murphy et al. (2006) compared moldboardplowed, chisel-plowed, and no-tilled systems for $6 \mathrm{yr}$ and found that weed dynamics were affected substantially by tillage systems. However, their respective efficiency declined with increasing density of weeds.

Tillage Systems and Weed Dynamics. Tillage systems interact with soil type, cropping system, and weed flora to affect weed dynamics and weed management (Table 1). Weed germination, stand 
establishment, and subsequent growth are affected by the tillage processes (Clements et al. 1996). Changing weed flora under different tillage regimes calls for a change in management options. Weed infestation is a serious problem during initial years under conservation tillage, which causes a reduction in crop yield (Blackshaw et al. 2001). On the other hand, some weed species may be suppressed in conservation tillage systems. For instance, wheat (Triticum aestivum L.) planting in no-till conditions reduced the seedling emergence rate of littleseed canarygrass (Phalaris minor Retz.), when compared with conventional plowing and sowing (Franke et al. 2007).

Tillage systems may also affect weed seed bank persistence in different seasons, but literature on this event is not clear. Effects of tillage on weeds are very specific and may vary from species to species. Emergence of tropical crabgrass [Digitaria bicornis (Lam.) Roemer \& J.A. Schultes ex Loud.], tumble pigweed (Amaranthus albus L.), giant foxtail (Setaria faberi Herrm.), and common ragweed (Ambrosia artemisiifolia L.) was suppressed by spring cultivation, whereas that of velvetleaf (Abutilon theophrasti Medik.) and black nightshade (Solanum nigrum L.) was unaffected (Myers et al. 2005). Similarly, tillage had different effects on the distribution of common lambsquarters (Chenopodium album L.) and yellow foxtail [Setaria glauca (L.) Beauv.] in different seasons (Myers et al. 2005). Chauhan et al. (2006) also reported that weeds respond differently under different tillage regimes. For instance, intensive tillage may affect small-seeded weeds like squirreltail fescue [Vulpia bromoides (L.) S.F. Gray] through deep burial. Different tillage systems may have their own advantages and disadvantages in this regard but site-specific selection may facilitate weed management.

Strip Tillage to Target Weeds. No-till is a pragmatic option for resource conservation in many regions of the world but one serious concern in this system is poor crop establishment. Strip tillage is one such innovative approach focusing on targeted tillage for crop sowing while the remaining portion is untilled. This system improves soil quality, crop yield, and resource-use efficiency compared with a conventional tillage system, but weed management is a major issue hindering its adoption (Brainard et al. 2012). Weed dynamics are very complex under this system since the untilled zone may offer refuge to different predators and may utilize less mineralized nitrogen $(\mathrm{N})$. In this way, the situation and distribution of weeds are highly variable (Tarkalson et al. 2012). The tilled zone has well-incorporated residues, fertilizer, mineralized $\mathrm{N}$, and higher temperatures, which contrast with the adjacent untilled patch. Such diversified conditions through targeted tillage directly alter weed dynamics as propagule movement and belowground biological functions are affected (Haramoto and Brainard 2012).

Winter annual weeds like common chickweed [Stellaria media (L.) Vill.] and henbit (Lamium amplexicaule L.) were more prevalent in the strip tillage system when compared with the conventional tillage (Brainard et al. 2012). This may be due to high survival and reproduction in the untilled portion. According to Brainard et al. (2013), perennials like horsenettle (Solanum carolinense L.) have the ability to recolonize quickly and are more problematic under strip tillage. Stable perennials like dandelion (Taraxacum officinale G.H. Weber ex Wiggers) do not usually present this problem. Overall, annual, biennial, and perennial weeds have a different growth and emergence pattern under strip tillage (Brainard et al. 2012).

Weed Control through Tillage Rotation. Rotation of tillage intensity (number of operations) is a modern approach for weed management, especially under multiple cropping systems. In an experiment spanning $6 \mathrm{yr}$, it was observed that the density of summer annual weeds was reduced significantly when zero-tilled direct seeding was replaced with full-width tillage (Peachey et al. 2006). Another potential strategy is by adjusting crop rotations in such a way that the planting geometry automatically rotates the tillage patterns. For example, in the Pacific Northwest, vegetables on wider beds are rotated with cereals on narrow ridges (Brainard et al. 2013). In another study, foxtail barley (Hordeum jubatum L.) was effectively controlled through shifting from no-till to primary tillage with moldboard plow followed by disking in spring wheat (Donald 1990). Timing of tillage is another important factor affecting weed management.

Tillage affects weed dynamics, depending on seasonal variations, weed species, and type of tillage implement. There are numerous other factors, though, that are interacting and making such assumptions less solid and therefore more complicated.

\section{Crop Nutrient Management}

The role of nutrient management through fertilizer application in crop production is substantial 


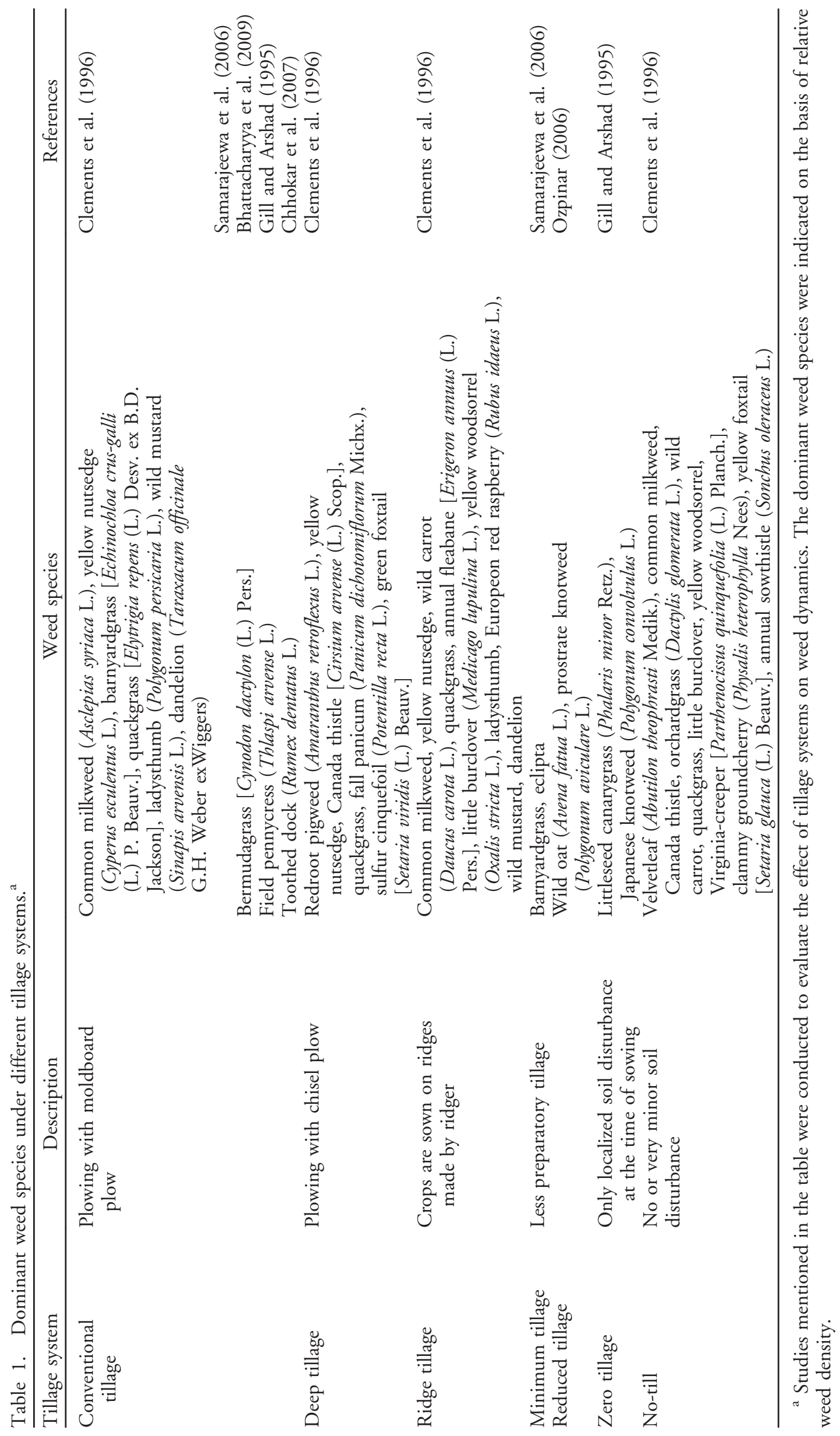

726 - Weed Science 63, October-December 2015 
and very clear. Weeds take up significant amounts of nutrients, just like crops. But the comparative effects on weed growth, population, distribution, and proliferation are generally ignored. Significant research in this area has shown that there exists a strong relationship between nutrient management and weed behavior and management. In a recent review, Bajwa et al. (2014) concluded that fertilizers affect weed growth, development, distribution, dynamics, persistence, emergence, and competitiveness.

Proper crop nutrient management can play a pivotal role in weed management. Different weeds show a variable response to nutrient management. For instance, dynamics of Persian darnel (Lolium persicum Boiss. \& Hohen. ex Boiss.), wild oat (Avena fatua L.), and spineless Russian thistle (Salsola collina Benth.) were not affected by $\mathrm{N}$ fertilization, whereas redroot pigweed (Amaranthus retroflexus L.) was significantly affected (Blackshaw and Brandt 2008). The possible interactions might be due to the effect of fertilizer on weed-crop competition (Evans et al. 2003). Nutrient availability may alter the weed-crop competition duration. In a study, the application of $\mathrm{N}$ fertilizer changed the emergence pattern, density, and competitive ability of different weeds (Sweeney et al. 2008). N uptake and assimilation rates were reported to be quite higher in redroot pigweed and common lambsquarters as compared with the crop plants, making them more competitive and successful (Lindsey et al. 2013). Increased supply of nutrients over a period of time may reduce weed density but increase total weed biomass (Mohammaddoust-eChamanadad et al. 2006). Variable weed responses to fertility suggest that weeds can be controlled through regulating fertilizer management (DiTomaso 1995). Varying fertilizer doses, application timings, and methods can modify weed-crop competition (Blackshaw et al. 2004; Cathcart and Swanton 2003; Mesbah and Miller 1999).

The nature of fertilizers may affect weed biology and ecology. The rate of a particular fertilizer may also improve or suppress the emergence and persistence of a particular weed (Cathcart and Swanton 2003). Yin et al. (2005) reported that the percent abundance of shepherd's purse [Capsella bursa-pastoris (L.) Medik.], Japanese bindweed (Calystegia hederacea Wallich), fixweed [Descurainia sophia (L.) Webb. ex Prantl], catchweed bedstraw (Galium aparine L.), swamp smartweed [Polygonum amphibium (L.) var. emersum Michx.], cone catchfly (Silene conoidea L.), and bird vetch (Vicia cracca L.) was highly variable because of variation in the $\mathrm{N}-\mathrm{P}-\mathrm{K}$ source (inorganic and organic). Palmer amaranth (Amaranthus palmeri S. Wats.) was reported to be highly responsive to the increased fertilization rate (Ruf-Pachta et al. 2013). Toler et al. (2004) observed that normally weeds respond positively to the starter fertilizer dose and grow well. It is suggested that a specific amount of fertilizer can provide better crop growth but an over- or underapplication may facilitate the competing weeds, resulting in yield losses (Major et al. 2005). Shifting the $\mathrm{N}$ application from the spring season to the fall season reduced the density and biomass of four noxious weeds, including wild oat, green foxtail [Setaria viridis (L.) Beauv.], wild mustard (Sinapis arvensis L.), and common lambsquarters (Blackshaw et al. 2004). Therefore, proper consideration must be given to fertilizer type, dose, and application timing when devising weed management strategies.

Above all, the role of nutrient placement in weed management is crucial. Most of the weed seeds are present near the soil surface and fertilizer application in that zone may promote their emergence and subsequent growth as well (Guza et al. 2008). Blackshaw et al. (2004) reported up to $68 \%$ weed reduction in cases where $\mathrm{N}$ was injected rather than broadcast. Surface banding of N and P reduced weed pressure because of less availability to weeds as compared with broadcasting (Blackshaw 2005). Significant reductions in the shoot biomass of wild oat and green foxtail were observed when $\mathrm{N}$ fertilizer was applied through banding and injection rather than broadcasting (Blackshaw et al. 2004). Recently, Chauhan and Abugho (2013) reported a significant reduction in weed biomass by the subsurface fertilizer application in dry direct-seeded rice (Oryza sativa L.).

Better management of crop nutrition can improve weed management. Fertilizer type, dose, timing, and application method must be selected to best manage weed populations given their link.

\section{Weed Seed Destruction}

Most of the annual weeds produce a majority of seeds after completing their vegetative growth. Many seeds are retained in the soil seed bank, which creates problems after emergence in standing crops. Weed populations can be decreased by removing their seeds at maturity (Walsh et al. 2013). This strategy eliminates potential seeds from the system that can be deposited in soil or may germinate in coming seasons.

Bajwa et al.: Nonconventional weed management • 727 
Table 2. Efficiency and adoption of harvest weed seed control systems in Australia. ${ }^{a}$

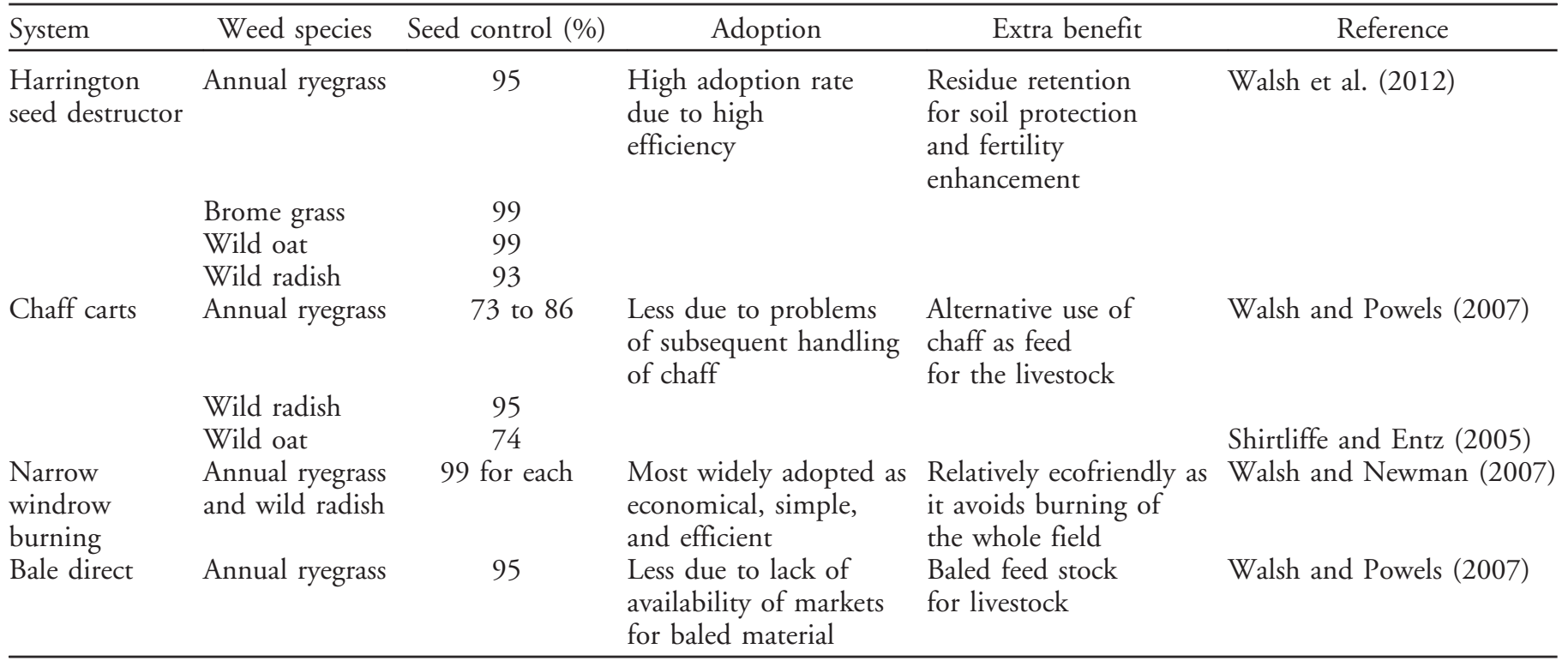

Harvest Weed Seed Control. The harvesting time of grain crops is very important as weed seeds are retained by plants and easy to remove and discard (Walsh and Powles 2007). Weed seeds can be collected and destroyed during or soon after harvesting of a crop. Harvest weed seed control has been developed in Australia and has shown promising results. This strategy can be implemented with the Harrington seed destructor (HSD), chaff carts, narrow windrow burning, and bale direct (Walsh et al. 2013). Each technology is based on the principle of weed-seed collection during grain crop harvest and seed destruction to avoid the replenishment of the seed bank.

Harrington Seed Destructor. Weed seeds present in annual grain crops remained a major concern for growers. A progressive grain producer, Ray Harrington, from Australia tested a cage mill for seed destruction in 2005 (Walsh et al. 2013). Cage mills are normally used to crush stone materials. Further research enabled scientists to destroy up to $90 \%$ of seeds of annual ryegrass (Lolium rigidum Gaudin) contained by wheat chaff during harvesting (Walsh et al. 2012). HSD is a modified cage mill having a chaff-and-straw transfer system along with power source. According to Walsh et al. (2012), field studies showed that HSD offers an impressive destruction rate of above $95 \%$ for annual ryegrass, ripgut brome (Bromus diandrus Roth), wild radish (Raphanus raphsnistrum L.), and wild oat seeds (Table 2). With such impressive results, HSD is a pragmatic option for the destruction of weed seeds.
Chaff Carts. Weed seeds that remain intact during conventional harvesting operations that are then added to the crop residues become randomly distributed to the whole field. To avoid this problem, chaff carts were introduced. Chaff carts are simply a cart on a trailer that is attached to a harvester that collects the chaff and places weed seeds in a specified bin (Walsh et al. 2013). Chaff carts effectively collect a significantly large amount of seeds of obnoxious weeds like annual ryegrass, wild oat, and wild radish (Shirtliffe and Entz 2005; Walsh and Powles 2007). Collected weed seeds and chaff are then dumped in piles to be burned.

Narrow Windrow Burning. This technique for controlling harvested weed seed is where chaff and residues containing weed seeds are concentrated in a narrow windrow during harvesting (Walsh et al. 2013). The harvester-mounted chute makes about a $60-\mathrm{cm}$ windrow that is burned later, while keeping ecoprotection in mind (Walsh and Newman 2007). The limited burning of the windrow avoids pollution hazards as the whole field is not burned. Windrow burning is promising as it offers maximum weed control after harvesting of wheat, canola (Brassica napus L.), and garden lupin (Lupinus polyphyllus Lindl.) (Table 2).

Bale Direct. This is another sophisticated method of harvest weed seed control, in which chaff and residues from the harvester are converted into bales by a mechanized baler attached to the harvester (Walsh et al. 2013). Despite its efficient and clean 
function, the adoption rate is lower, which may be due to the marketing issue with bales. However, it offers remarkable weed seed destruction (Table 2).

Hence, weed seed control during crop harvest is an encouraging prospect in the field of weed management. It helps to reduce weed seed bank and to minimize the chances of weed infestations in subsequent seasons. The development of technology in this sector may enable the farming community to manage weeds efficiently.

Weed Seed Predation. Seed predation through granivorous insects and small mammals is a useful tactic for weed control. Seed predation may be pre(seeds still attached with plant) or post- (seeds dispersed after maturity) dispersal. Insects, birds, and small mammals are the major postdispersal weed seed predators (Heggenstaller et al. 2006; Menalled et al. 2007). Most Coleoptera and Hymenoptera insects are involved in weed seed feeding. Several species of carabid beetles and field cricket have been observed as potential predators of redroot pigweed, velvetleaf, large crabgrass [Digitaria sanguinalis (L.) Scop.], and giant foxtail seeds in North America (Carmona et al. 1999). Mice consumed up to $20 \%$ of seeds of barnyardgrass [Echinochloa crus-galli (L.) P. Beauv.] and common lambsquarters in no-till soybean [Glycine $\max$ (L.) Merr.] and corn (Zea mays L.) in Canada (Carmona et al. 1999). Feeding habits and preferences of the predators significantly affect weed seed destruction and concomitant weed emergence. White et al. (2007) observed feeding choice of three beetle species (Amara aenea, Anisodactylus sanctaecrucis, and Harpalus pensylvanicus) and the field cricket (Gryllus pennsylvanicus). The beetles consumed more seeds of redroot pigweed than of giant foxtail.

Experimental and modeling studies have clearly shown that predation significantly affects weed seed demographics (Mauchline et al. 2005). A recent study in the Philippines reported a seed removal rate of 78 to $91 \%$ for junglerice [Echinochloa colona (L.) Link], goosegrass [Eleusine indica (L.) Gaertn.], and southern crabgrass [Digitaria ciliaris (Retz.) Koel.] over a 14-d period (Chauhan et al. 2010). Meiss et al. (2010) reported that the vegetative cover influences weed-seed predators by altering the habitat quality. Effective predation can be achieved by delaying tillage or increasing interval between land preparation and seeding (Chauhan 2012; Chauhan et al. 2010). Seed predation is a potential nonchemical weed management option. It can be used alone or in combinations with other cultural management practices.

\section{Allelopathy}

A large proportion of the existing allelopathy research findings is focused on its role in weed management. Researchers have observed that allelopathy is a great organic weed management tool (Cheema et al. 2004; Iqbal et al. 2007; Jamil et al. 2009). Allelochemicals suppress physiological functioning of plants and thus retard growth when applied at high concentrations. This phytotoxic activity of allelochemicals is responsible for growth suppression of weeds (Farooq et al. 2013). Allelopathy can be expressed in two major ways for weed management: cultural means and allelopathic extracts application.

Cultural Means. Allelopathic sources can be introduced through crop rotations. Allelopathic crops are included in a planned rotation where their residual effects may suppress weed flora and provide a weed-free environment to the next crop. Mulches based on allelopathic residues are good means of weed control (Cheema et al. 2013). Emerging weed seedlings are effectively controlled by allelopathic mulches through the leaching of allelochemicals; however, established weed flora is difficult to eradicate through this method (Farooq et al. 2013). Similarly, incorporation of sorghum [Sorghum bicolor (L.) Moench ssp. Bicolor] vegetative parts significantly reduced weed density in wheat fields (Cheema and Khaliq 2000). Soil incorporation of sorghum residues alone and when mixed with sunflower (Helianthus annuus L.), rice, and Brassica spp. trashes provided effective control against littleseed canarygrass, common lambsquarters, toothed dock (Rumex dentatus L.), and horse purslane (Trianthema portulacastrum L.) in wheat, cotton (Gossypium hirsutum L.), and corn fields (Table 3). Surface mulching of sorghum, brassica, and cone marigold (Tagetes minuta) controlled weeds in rice, cotton, and mung bean [Vigna radiata (L.) R. Wilczek] (Batish et al. 2007; Khaliq et al. 2010; Sadia et al. 2013). Intercropping is another prospect for weed management through allelopathy (Table 3). Allelopathic crops can also be introduced as cover and smother crops. Allelopathic crops like rye (Secale cereal L.), velvet bean [Mucuna pruriens (L.) DC.], and barley (Hordeum vulgare L.) offered effective control against southern crabgrass, barnyardgrass, common purslane, and Amaranthus 


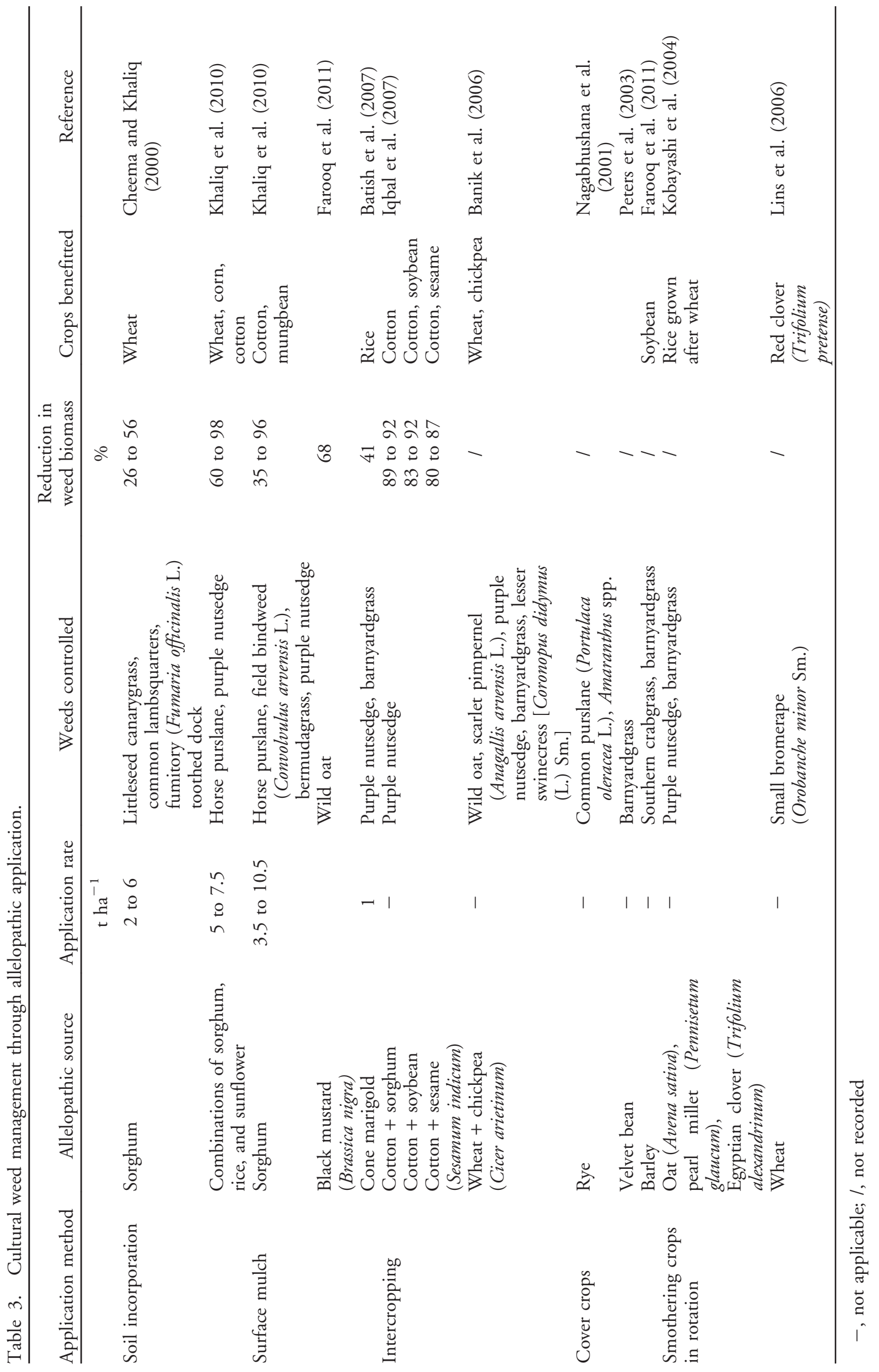

730 - Weed Science 63, October-December 2015 
spp. in different crops (Farooq et al. 2011). Cultural means of allelopathic application have varying degree of success, depending upon environmental and managerial factors.

Allelopathic Extracts. Allelochemicals are secondary metabolites with complete solubility in water. This feature enables them to be extracted in water after soaking herbage and subsequently used as foliar spray. Crop water extracts have been used successfully for weed suppression through foliar application in different crops (Bajwa 2014). Sorghum water extract is one of the most widely used natural herbicides. Concentrated sorgaab (sorghum water extract) controlled common lambsquarters, littleseed canarygrass, and toothed dock in wheat crop (Cheema and Khaliq 2000). Similarly, it offered a substantial reduction in weed density and weed biomass in rice, cotton, corn, and mungbean (Table 4). Combined use of different crop water extracts improves weed management through synergistic effects (Table 4). In a laboratory experiment, Bajwa et al. (2013) showed that single and combined applications of water extracts of some tree plants and weeds suppressed the germination and growth of wild oat. Integrating the use of half doses of recommended chemical herbicides and different crop water extracts together offered favorable weed control (Jabran et al. 2010; Rehman et al. 2010).

Improving Allelopathic Potential of Crops. Improvement in the allelopathic potential of crops to offer a substantial competitive advantage against resistant weeds is under way. Keeping in view the genetic variability existing in cereals, crops have been bred to improve their allelopathic potential (Worthington and Reberg-Horton 2013). Modified lines of birdsrape mustard (Brassica campestris L.) have been developed to increase their allelopathic expression, which offered successful weed control in corn and soybean (Haan et al. 1994). Highly weedsuppressive rice genotypes (e.g., hybrid of Kouketsumochi and IR24) have been developed through conventional breeding, which suppress noxious weeds like junglerice and red rice (Oryza sativa L.) to a great extent. Such cultivars are commercially available in China and the United States (Fragasso et al. 2013). Improvement in the allelopathic potential of crops through genetic engineering is among the latest trends in the field of agrobiotechnology (Nawaz et al. 2014). Despite the complex genomics, it is feasible to identify the distinguished genes involved in such mechanisms (Singh et al.
2003). Wu et al. (2000) screened a large pool of winter wheat accessions (over 400) to assort allelopathic active genes. With the help of genetic tools, genes have been located that are responsible for the production of allelochemicals. Location of such genes on chromosomes and quantitative trait loci (QTLs) are also being assessed (Jensen et al. 2008). Gene mapping for hydroxamic acid expression in wheat has been analyzed and QTLs are being used for gene transfer (Wu et al. 2000, 2003). Crops with superior allelopathic profile and suppressive ability will improve weed management in coming days.

\section{Herbicide-Tolerant (HT) Crops}

An increasing trend of genetic modifications in crops has been observed during the last 2 decades. Major transgenic traits introduced in crops are herbicide resistance, insect resistance, virus resistance, and stress resistance. However, HT crops comprise the vast majority (83\%) of genetically modified (GM) crops (Beckie et al. 2006). The reason behind the introduction of HT crops and their rising acceptance is primarily due to the effective weed control. Biotechnology has provided successful HT crops that are tolerant to glyphosate, glufosinate, bromoxynil, imidazolinone, and dicamba (Gealy et al. 2003; Givens et al. 2009). HT crops like cotton, corn, canola, rice, sugar beet (Beta vulgaris L.), alfalfa (Medicago sativa L.), brassica, and soybean (Gealy et al. 2003) have revolutionized weed management in the United States (Givens et al. 2009), Canada (Beckie et al. 2006), Australia (Duke and Powles 2009) and many other countries.

A majority of HT crops, including soybean, cotton, corn and canola, is glyphosate resistant (GR) (Green 2012). GR crops have the largest share in transgenic HT crops globally. GR cotton was also adopted quickly in the United States and other countries because of convenience and effective weed management. Singh (2014) reported that $>95 \%$ of cotton varieties planted in the United States were GM varieties where area under stacked gene cotton varieties increased from $24 \%$ (2000) to $77 \%$ in 2014. Weed management in the conventional nonHT cotton was difficult because of the narrow spectrum and ineffectiveness of PRE herbicides (Duke and Powles 2009). GR canola has been successful in different parts of world. However, about $90 \%$ of the global GR canola production is in Canada (Gianessi 2005). HT soybean is the most

Bajwa et al.: Nonconventional weed management $\quad 731$ 


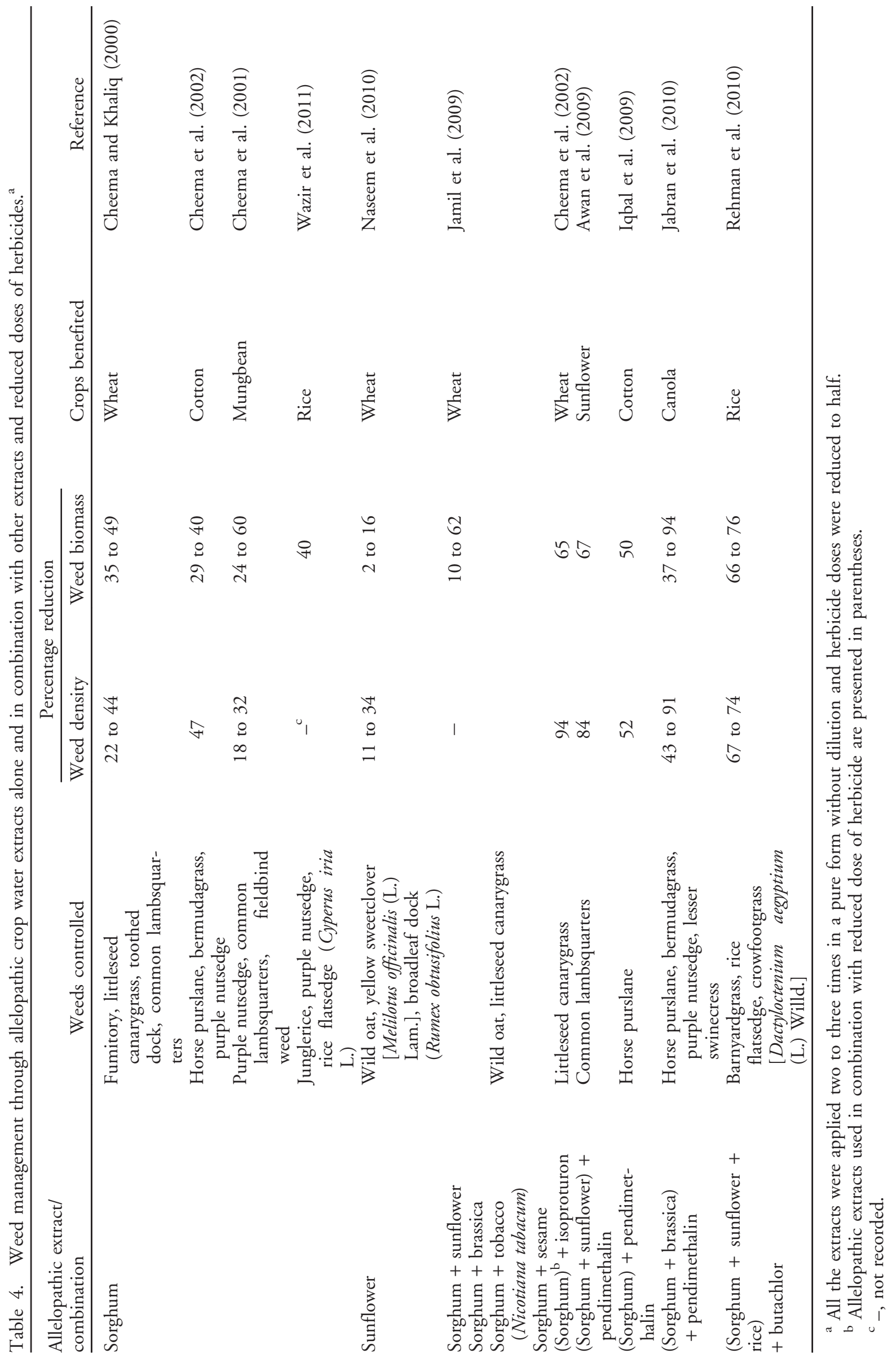

732 - Weed Science 63, October-December 2015 
prevalent, where around $60 \%$ of the total production is transgenic crops (Beckie et al. 2006).

Nontransgenic HT corn, canola, wheat, soybean, sunflower, and sorghum developed in the past were tolerant to imidazolinones, photosystem II inhibitors, and sulfonylureases (Green 2012). Clearfield (CF) rice is exclusively nontransgenic, developed through the breeding technique, relying totally on rice DNA. CF rice is resistant against imidazolinone herbicide, which is very effective against red/weedy rice. Weed control in CF rice is very easy as it allows PRE and POST application of imazethapyr (Azmi et al. 2012). Wheat is the crop in which biotechnology has not given successful commercial varieties yet. A lot of work is under progress at Monsanto, Bayer, BASF, and many other multinational companies for biotechnological development in wheat. Research trials have shown that Roundup Ready wheat is safe, nutritious, and efficient in terms of weed management (Obert et al. 2004). However, its commercialization has not taken place.

Critics of HT crops raise concerns about environmental hazards, health issues, biodiversity decline, and moral obligations. Above all, the conundrum of herbicide resistance development in weeds has seriously threatened the sustainable use of HT crops as a weed management option (Heap 2014). No doubt, HT crops are playing a remarkable role in weed management but a serious problem remains the leakage of resistant genetic traits from crops to the associated weeds (Owen and Zelaya 2005). To allay the problem of herbicide resistance in weeds, a second-generation phase of HT crops is being developed (Mortensen et al. 2012). In the future, integrated approaches on the basis of stacked gene crops and rotational use of herbicides may offer effective weed control in different cropping regimes.

\section{Bioherbicides}

Bioherbicides are potential plant pathogens applied to agroecosystems exogenously and repeatedly to control weeds. Biological weed control gained traction in the mid-80s when some of the potent pathogens were successfully utilized to make effective formulations for weed control. Despite its early gains, this particular field is still struggling regarding inventions or launching products, but consistent theoretical development is still evident (Hallett 2005). Given the changing climate, evolution of herbicide resistance in weeds, and lagging science of synthetic herbicides, innovations in the field of bioherbicides are much needed (Charudattan and Dinoor 2000). Currently, eight bioherbicides have been registered and are being commercialized. These products have been proven effective in specific weed management scenarios and helped a great deal in effective integrated weed management. Most of them include fungal pathogens and are based in the United States or Canada. Over 200 plant pathogens have been identified for use of this purpose after considerable technological developments (Hoagland 1996). Biotechnology has a pivotal role in the development and modification of bioherbicides. Advancements in screening, formulation, augmentation, and application of bioherbicides depend upon biotechnological tools (Ghosheh 2005).

Bioherbicides have some unique advantages, making them suitable for weed management in a variety of environments. One of the most important benefits of bioherbicides is their specific action. There are no side effects like residual toxicity, nontarget destruction, or health issues (Charudattan and Dinoor 2000). However, the role of bioherbicides in modern weed management is complementary rather than exclusive. They lack attributes to be considered as a solo scavenger (Hoagland et al. 2007). There are many limitations and constraints in the implementation of bioherbicides in weed management (Table 5). Comprehensive research on genetic, biological, environmental, technological, and financial aspects of this technology is recommended.

\section{Thermal Weed Management}

Plant tissues are susceptible to high temperatures, when most of the physiological functions are disrupted because of membrane rupture, protein denaturation, and enzyme inactivation. This led to the development of weed management strategies involving high temperature. Most of the plants die after exposure temperatures between 45 and $55 \mathrm{C}$ (Zimdahl 2013). To control weeds, heat may be used in different ways, including direct flaming, solarization, and microwave technology.

Flaming. Flaming is a unique technique to kill weeds through the use of direct heat in the form of fire. The temperature of about $55 \mathrm{C}$ is used to kill the weeds by destroying the cell wall structure. Fuel and temperature requirements depend on weed growth stage and biomass. However, for effective weed control, frequent flaming is often needed (Ascard 1994). Commonly, propane is used as fuel,

Bajwa et al.: Nonconventional weed management • 733 
Table 5. Limitations in bioherbicide development.

\begin{tabular}{|c|c|c|c|c|}
\hline \multicolumn{3}{|c|}{ Limitations } & \multirow[b]{2}{*}{ Suggested measures } & \multirow[b]{2}{*}{ Reference } \\
\hline Type & Factors & Processes affected & & \\
\hline Environmental & $\begin{array}{l}\text { Effect of temperature, } \\
\text { dew period, relative } \\
\text { humidity, rainfall; } \\
\text { environment of } \\
\text { phyllosphere }\end{array}$ & $\begin{array}{l}\text { Formulation } \\
\text { and efficacy }\end{array}$ & $\begin{array}{l}\text { Frequent applications, improvement } \\
\text { in formulation process, use of } \\
\text { vigorous pathogens, improved } \\
\text { application technology }\end{array}$ & $\begin{array}{l}\text { Charudattan and } \\
\text { Dinoor (2000); } \\
\text { Ghosheh (2005); } \\
\text { Hallett (2005); } \\
\text { Scheepens et al. (2001) }\end{array}$ \\
\hline Biological & $\begin{array}{l}\text { Host specificity, resistance, } \\
\text { infection period, and } \\
\text { narrow spectrum }\end{array}$ & $\begin{array}{l}\text { Formulation, } \\
\text { infection, } \\
\text { effectiveness, } \\
\text { augmentation }\end{array}$ & $\begin{array}{l}\text { Genetic improvement, } \\
\text { stacking technology to widen } \\
\text { the effectiveness spectrum, } \\
\text { integration with chemical } \\
\text { herbicides }\end{array}$ & $\begin{array}{l}\text { Auld and Morin (1995); } \\
\text { Charudattan (2001, } \\
\text { 2005) }\end{array}$ \\
\hline Technological & $\begin{array}{l}\text { Pathogen strain } \\
\text { identification, } \\
\text { shelf life, application } \\
\text { techniques }\end{array}$ & $\begin{array}{l}\text { Formulation, } \\
\text { application }\end{array}$ & $\begin{array}{l}\text { New formulations, } \\
\text { use of surfactants and } \\
\text { adjuvants to improve } \\
\text { application and efficacy }\end{array}$ & $\begin{array}{l}\text { Ghosheh (2005); } \\
\text { Patzoldt et al. (2001) }\end{array}$ \\
\hline Legal & $\begin{array}{l}\text { Rigid registration } \\
\text { laws, dominating } \\
\text { chemical herbicide } \\
\text { industry }\end{array}$ & $\begin{array}{l}\text { Registration, } \\
\text { dissemination }\end{array}$ & $\begin{array}{l}\text { Restructuring registration } \\
\text { laws and extension policies }\end{array}$ & Ghosheh (2005) \\
\hline Financial & $\begin{array}{l}\text { Funding for } \\
\text { research programs, } \\
\text { commercialization }\end{array}$ & $\begin{array}{l}\text { Overall } \\
\text { development } \\
\text { and progress of } \\
\text { bioherbicides }\end{array}$ & $\begin{array}{l}\text { Allocation of funds for } \\
\text { integrated programs based on } \\
\text { bioherbicide development, } \\
\text { development of } \\
\text { cross-disciplinary projects }\end{array}$ & $\begin{array}{l}\text { Ghosheh (2005); } \\
\text { Hallett (2005); } \\
\text { McConnachie et al. (2003) }\end{array}$ \\
\hline
\end{tabular}

but relatively renewable alternatives like hydrogen are also under consideration (Andersen 1997). Flame weeding is most prevalent in European countries (Bond and Grundy 2001). Weeds that have thin leaves like common lambsquarters, nettle, and chickweed are readily burnt through flaming, whereas shepherd's purse, barnyardgrass, and annual bluegrass (Poa annua L.) could not be burnt in a single operation (Ascard 1995). Flaming has shown good results after weed emergence but before crop emergence in potato (Solanum tuberosum L.), sugar beet, carrot (Daucus carota L.), and cayenne pepper (Capsicum annuum L.) (Melander 1998). Rask et al. (2012) studied the effect of flaming on grasses and shared some positive results regarding the control of grasses. Knežević and Ulloa (2007) evaluated broadcast flaming in different agronomic crops to manage barnyardgrass, green foxtail, velvetleaf, and redroot pigweed and concluded that flaming offers best control for broad-leaved weeds, whereas the grasses are less susceptible. Corn and sorghum (both from the Poaceae family) were tolerant to flaming, whereas soybean and sunflower were susceptible (Knežević and Ulloa 2007). Weeds of corn were significantly controlled through integration of tillage and flaming (Knežević et al. 2011).

Flaming has provided effective weed control in different ecosystems and has led to system stability.
In many regions, fire is not a threat but a tool to reduce competition and to improve nutrient cycling (Kyser and DiTomaso 2002). A quick response and prompt results are also the distinct features of flame weeding. With advancement in this subject, logistic models have been developed to estimate the efficiency of flame weeding and species response to flaming (Ascard 1995). Further research is needed to optimize the technology for its safe use in field crops.

Solarization. Solarization is a practice of covering the soil with plastic sheets, converting solar energy to heat to kill weeds before sowing of the crop. Soil sterilization is an effective approach toward weed management by applying steam directly to kill weeds or by solarization. It suppresses weed germination and kills existing seedlings (Horowitz et al. 1983). Additional benefits of solarization are improved crop germination due to optimal temperature attainment and destruction of plant pathogens due to the sterilization effect of heat. Winter annual weeds were found to be more sensitive to solarization, but summer annuals like crabgrass and common purslane were less affected by heat. Perennials like bermudagrass (Cynodon dactylon L.), Johnsongrass [Sorghum helepense (L.) Pers.], and field bindweed (Convolvulus arvensis L.) 
were least affected by solarization because of their well-developed underground parts (Horowitz et al.1983; DeVay et al. 1991). Solarization duration and its interaction with cultivated soil depth cause significant difference in weed control. It works more efficiently in tilled soils. Solarization along with green manuring suppressed annual bluegrass significantly (Peachey et al. 2001). Integrated use of polyethylene sheets and poultry manure mulch affected emergence of field dodder (Cuscuta campestris Yuncker) (Haidar and Sidahmed 2000). Solarization for 2 mo with polyethylene covering killed $95 \%$ of broomrape (Orobanche ramosa L.) seeds (Mauromicale et al. 2005). The success of solarization depends upon exposure to light, soil texture, moisture status, and weed flora. It is a pragmatic option and has vast implications for integrated weed management.

Microwaves and Radiations. Use of microwave energy to kill weeds has gained popularity in the recent past. It is based on the high energy of microwaves, which can kill weeds very efficiently. This method is highly targeted and there is no fear of nontargeted damage (Rask and Kristofferson 2007). Microwaves were successfully used in Denmark for the control of little mallow (Malva parviflora L.), hairy fleabane [Conyza bonariensis (L.) Cronq.], and gooseberry gourd (Cucumis myriocarpus E. Mey. ex Naud.) (Brodie et al. 2007). This technology is effective against many weeds, but the energy required is very high, which increases its cost (Sartorato et al. 2006). However, its efficiency and energy budget may be decreased by flux configuration and through induction of thermal runaway in weed plants, making it comparable with other weed-control tools in terms of cost (Brodie et al. 2011). Similarly, laser radiation may be used effectively to kill weeds (Rask and Kristofferson 2007). In the United States, laser beams were used to kill water hyacinth plants. Lasers transfer high energy to plant tissues and raise the water temperature at the cellular level, resulting in cell death. Mathiassen et al. (2006) studied the biological efficacy of laser treatment against common chickweed and scentless chamomile [Tripleurospermum inodorum (L.) Schultz-Bip.] under varying levels of exposure time and observed that weeds were significantly suppressed. Use of ultraviolet radiation for weed management has also been tested (Andreasen et al. 1999; Day et al. 1993) and it was observed that the ultraviolet energy acts severely on plant tissues. It kills weeds just like flaming; however, limited development of this technology is due to possible health hazards. Further research is needed in this particular aspect to develop economically viable options on a sustainable basis.

Hot Water, Steam, and Hot Air. Heat can also be used to kill weeds through hot water application. Hot water treatment for weed control has been trialed in many countries with a great deal of success (Rask and Kristofferson 2007). In the 1990s, a commercial tool, Aqua Heat, was developed in the United States to apply hot water for weed control (Berling 1992). Hot water application proved effective against most of the annual and a large number of perennial weeds. The effects were even comparable against a glyphosate application. Similar kinds of equipment were successfully used against weeds in New Zealand, where hot water remained in contact with weeds for a longer period of time (Rask and Kristofferson 2007). Hot water equipment for weed control is also available in Denmark and the Netherlands. Hot water treatment is safe and has no side effects like flame weeding or radiation methods. Its effectiveness is greater under dense weed population because of increased penetration ability (Hansson and Ascard 2002). Because of a greater success rate, this technique is being considered in precision weed management strategies in European countries. Use of steam instead of hot water has been observed as a more effective, quick, and sustainable method, especially in cases where weed control is on relatively hard surfaces (Rask and Kristofferson 2007). Engineering efforts are needed in this area to improve the efficiency of availability of equipment and to introduce new equipment for weed management in crop production regimes.

Electrocution. The practice of weed control via electric shock is called electrocution. Although it is a less-researched domain, evidence supports the fact that weeds can be killed by spark discharge or electrical contact (Diprose and Benson 1984; Parish 1990). The strength of electric shock, contact or exposure duration, weed species, morphological features, and growth stage significantly affect the success of electrocution. The severity of damage is aggravated in cases of dry soil conditions (Diprose and Benson 1984). However, because of higher costs involved, energy crises, and hazards to operators, its application in agriculture is limited. In the future, this particular method may have practical implications, especially in organic farming. 


\section{Precision Weed Management}

Precision weed management is based on bringing in information technology for decision making about site-specific weed control (Christensen et al. 2009). Spatial heterogeneity in weed infestation provides the basis for the implication of such systems. For instance, early-season site-specific weed management is the approach of weed patch detection, mapping, and prompt control through machine vision, while keeping the economic feasibility in mind (Freckleton and Stephens 2009).

Modeling. Modeling is a potential tool to assess the actual scenario of weed dynamics for the subsequent management strategies. Weed modeling is a relatively complex subject and several mathematical and statistical tools are used to form a precise model (Freckleton and Stephens 2009). Successful modeling that is based on the data collected through sensing technologies provides a clear picture about weed seed bank dynamics, emergence patterns, replacement trends, competitiveness, canopy architecture, and possible yield losses (Christensen et al. 2009; Rew and Cousens 2001). Decision-making tools and models help to identify and measure the influence of variables like soil conditions, environmental factors, crop husbandry practices and mechanization on weed emergence, distribution, and competition patterns (Christensen et al. 2009).

There are generally two aspects of weed modeling: one is efficacy based and the other is population based (Freckleton and Stephens 2009). Efficacybased modeling involves the assessment of control measures and their effectiveness (Wiles et al. 1996). It helps in making decisions about herbicide choice and dose for appropriate weed control. For instance, the weed model SELOMA helps to decide the suitable herbicide under prevailing conditions (Stigliani and Resina 1993). The precision of any model depends on details provided, number and nature of variables, and the validation process (Freckleton and Stephens 2009). On the other hand, population-based predictive models are intensively researched and are more prevalent in weed science. They are used to deliver information about weed infestation patterns, weed density, and weed cover in a given area over a period of time. Some of the most useful deterministic population models include HERB, WEEDSIM, GWM, PALEWEED, and GESTINF (Christensen et al. 2009; Freckleton and Stephens 2009).
The economic feasibility of a control measure can also be measured precisely through modeling where only cost-effective strategies may be considered (Christensen et al. 2009). Another beneficial aspect of weed modeling is the evaluation of weed-crop competition status (Christensen et al. 2003). The findings of a 5-yr study were encouraging, as the predictions about dose reduction, economic status, and competition intensity were precise (Christensen et al. 2009). Modeling for weed dynamics in wheat, sugar beet, corn, and barley also provided good results in terms of precision and decision support (Gerhards and Christensen 2003). The modeling approach is very impressive for the implementation of precision weed management; however, there are certain limitations with it. Most of the predictive decision support models rely on weed data that consider weed populations in even distributions and thus foresee the yield losses in an exaggerated manner. Similarly, the weed population trend may be misread sometimes, because of uneven weed distribution (Brain and Cousens 1990; Christensen et al. 2009). Problems related to input data, remote sensing, and choice of model may also influence the efficiency and precision of weed models. Fine tuning of the whole regime may improve the efficacy of modeling and consequently the implication of precision weed management.

Remote Sensing. Remote sensing is a modern technology used in agriculture to ensure the precision management of inputs as well as to frame out weed presence (Thorp and Tian 2004). Remote-sensing tools can be used to detect weed patches, or in other words, to map weed densities in field crops and forest areas. It is well known that weeds are mostly prevalent in patches on agricultural lands. Therefore, remote sensing is a good option to reduce the herbicide application and cost of production by enhancing the herbicide application efficiency (Medlin and Shaw 2000). Remote sensing is based on differential spectral reflectance of weeds and other vegetation, like crops and spectral resolution of the instrument in use. These two factors govern the efficacy of remote sensing in mapping weeds. It is a prerequisite that the pixel quality must be higher than the difference in reflective indices of vegetation. The higher this difference is and the sharper the pixels, the higher the quality of the picture will be, which is crucial for subsequent mapping (Zhang et al. 1998). On the other hand, stubbles or residues may hinder because of the similarity with emerging or even established 
Table 6. Weed species mapped against different background environments through remote sensing.

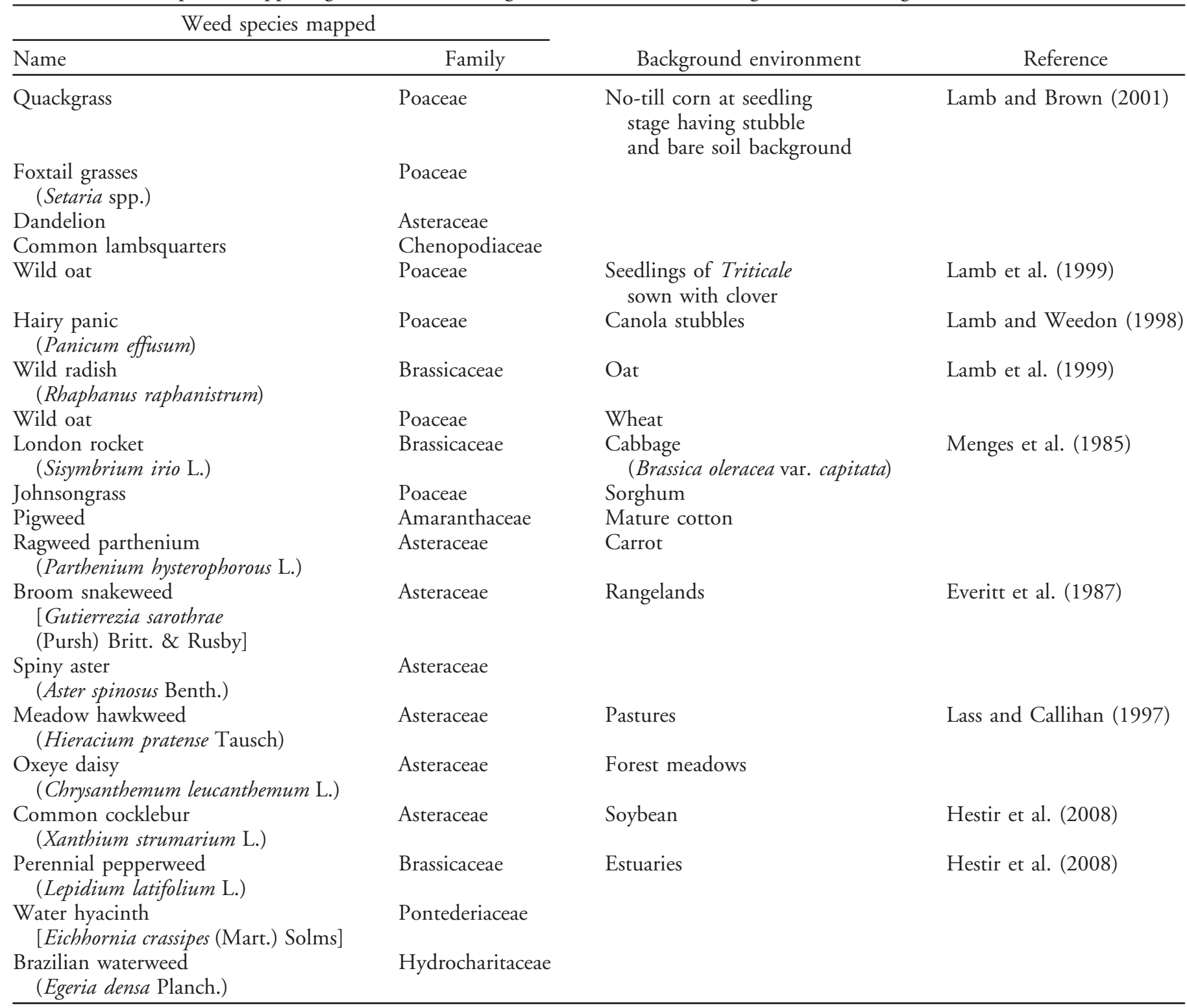

weed vegetation, which makes it hard to discriminate the living and nonliving vegetation. Similarly, at the earlier stages of the crop stand, this problem may be enhanced in part, but a simple solution is the comparison of images obtained with the maps of fallow land plots (Lamb and Weedon 1998).

Some weed species have been successfully mapped through remote sensing in cereal and legume crops, especially with higher-resolution imagery in row crops (Table 6). It was observed that weeds can be identified from visuals and can be discriminated from the background vegetation. The prime considerations about weed floristic composition, canopy architecture, and leaf dimensions have made it feasible to map them against different crops' background (Zhang et al. 1998). Differences in growth stages of weeds and crops, emergence patterns, growing habits, vigor, and characteristics at maturity also provide help in sensing them remotely to sketch fine and accurate maps (Lamb and Weedon 1998; Medlin and Shaw 2000). Some researchers use classification algorithms for POST weed sensing. These algorithms are actually based on statistical variability and the trend between the weed densities before crop emergence against bare soils and after expected populations (Lamb and Weedon 1998; Lass et al. 2005). In this way, remote sensing is currently being used for statistical modeling of weed distribution patterns (Lass et al. 2005). One such technique is geostatistics, which is used for descriptive analysis of weed aggregation and spatial variation (Medlin et al. 2000). Different methods of remote sensing are based on this principle; however, they differ in the position of 
the sensor, resolution used, and mapping orientation. Each has merits and demerits associated with efficacy of tools being used (Table 7).

Aerial and Satellite Remote Sensing. Aerial installation of weed sensors is a useful way to monitor a large area. This technique can be used for imaging weed vegetation as it provides an overhead view of the whole field. The use of aerial sensors for weed detection was started after the 1980s and has gained reasonable popularity since then (Thorp and Tian 2004). Color imaging was the first method used in this technology and which later developed into color infrared photography to better screen weeds from remaining vegetation. Reflective indices of the nearinfrared (NIR) spectrum were more variable as compared with those of visible spectrum (Price 1994). Noxious weeds of different arable crops were successfully detected and mapped with reasonable accuracy (Table 6). Spectral signature mixing in weed sensing through aerial sensing remains an issue and was only used for thematic classifications. Thus, weed infestation regions were delineated on the basis of statistical variability measurements. On the other hand, aerial tools are being successfully used to delineate weed boundaries in rangelands, as thematic classification is more appropriate in such systems (Medlin et al. 2000). However, computerbased weed sensing is still a useful option via aerial sensor data input. Airborne sensors are more flexible in their function and application.

Satellite images are used for weed sensing. It is very common to use global positioning systems (GPS) and geographic information systems (GIS) for spectral analysis, tracking, and aerial location detection - their role in weed detection, though, is rare and complex. Multispectral images are commercially available from different satellites (Stafford 2000). The IKONOS satellite offered 4-m resolution in a multispectral mode. Similarly, images from SPOT, AVHRR, and TM satellites are in the range of $30 \mathrm{~m}$ to $1.1 \mathrm{~km}$. These multispectral images fall within a wide range of visible, infrared (IR), and NIR spectrums (Lamb and Brown 2001; Lamb and Weedon 1998). In a previous study, Memon et al. (2011) surveyed and mapped noxious weed species of wheat and cotton in the cotton-wheat cropping system through GIS and GPS. Recent advancement in the use of aerial and satellite weed sensing is replacing color and color infrared imaging with hyperspectral and multispectral technologies. Multiband multispectral cameras have been introduced to take images of densely populated weed species; encouraging results have been observed (Hestir et al. 2008). The use of multispectral scanners is becoming popular in place of aerial or satellite imaging and video sensing. For instance, the compact airborne spectrographic imager is an airborne scanning device operated at a height of $1,200 \mathrm{~m}$ with great accuracy (Stafford 2000).

On-Ground Remote Sensing. To compensate for the problems associated with aerial and satellite remote sensing, ground-based sensing devices have been developed. On-ground remote sensing has a high degree of precision and efficiency. Photodetectors are actually used along with sensors. These give a very clear picture about weed infestation and density (Thorp and Tian 2004). On the basis of this principle, weed-detection model instruments have been developed. Hanks and Beck (1998) analyzed two commercially available systems, the Detectspray Model S-50 and the WeedSeeker Model PhD 1620, which use photoelectric sensor readings to trigger nozzles for a spraying application. Photoelectric sensors are not able to distinguish between crop and weeds; therefore, plastic spray hoods were used to prevent vegetation within the crop rows from triggering the spray (Thorp and Tian 2004).

Unmanned Aerial Vehicles (UAVs). Weed populations in patches make it difficult to assess the actual scenario from the remote images with very small pixels. Weeds growing against a soil or stubble background offer difficulty in gathering accurate information (López-Granados 2011; TorresSánchez et al. 2013). To address these issues, UAVs have been introduced in recent years. These are automated drones with fixed high-resolution cameras, able to fly at very low altitudes. Given their ability to fly immediately, frequent high-resolution imaging capabilities, capacity to capture images even under clouds, placement flexibility, and economic feasibility are the unique selling points of UAVs, which make viable tools for future automated weed management (Anderson and Gaston 2013; Peña et al. 2013; Torres-Sánchez et al. 2013 Xiang and Tian 2011). The use of UAVs in agriculture is still premature but encouraging. A UAV was used in monitoring glyphosate application to turf grasses through multispectral imaging (Xiang and Tian 2011). In another study, Primicerio et al. (2012) used a six-rotor UAV to sense vineyard growth through a multispectral camera. The use of acquisition, georeferencing, and mosaicking in UAV imaging has improved this 


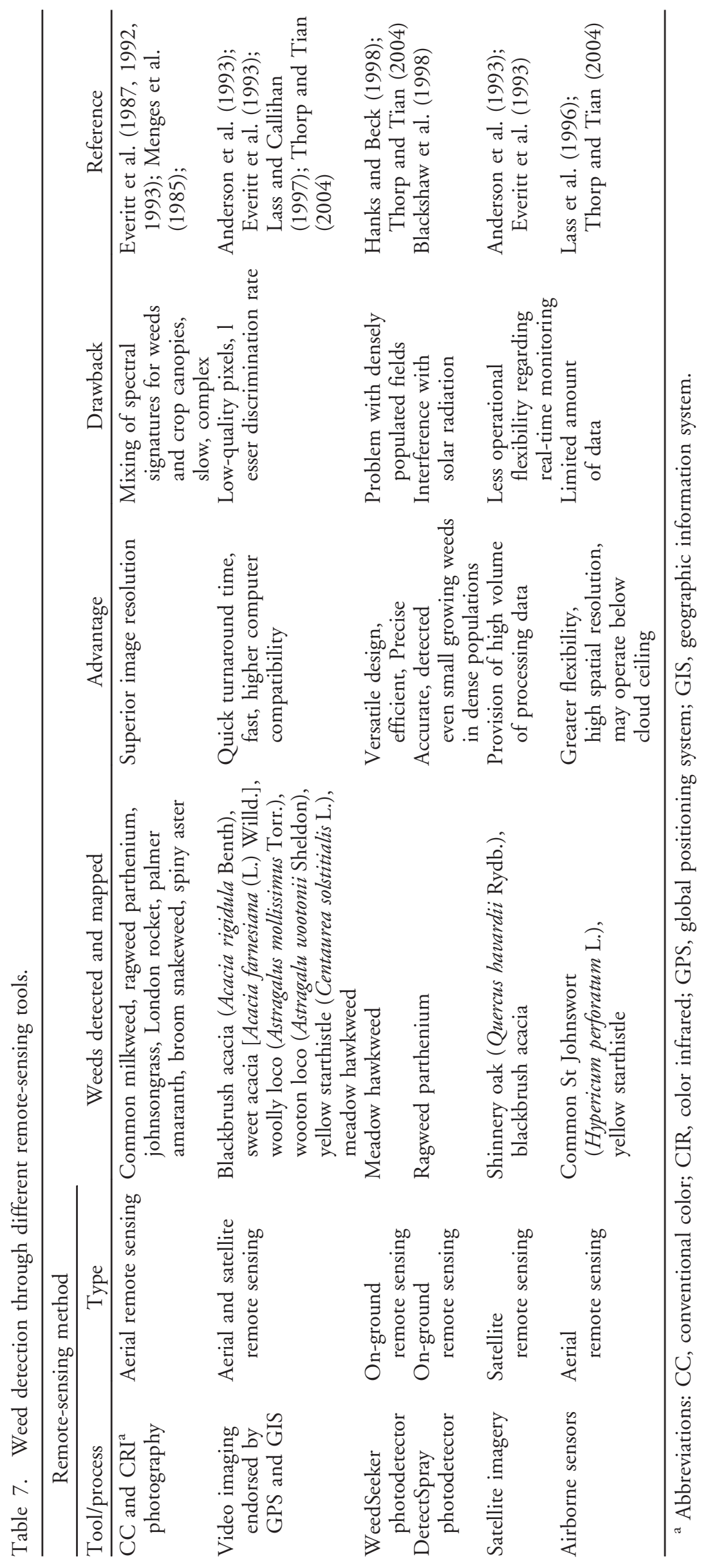

Bajwa et al.: Nonconventional weed management $\quad 739$ 


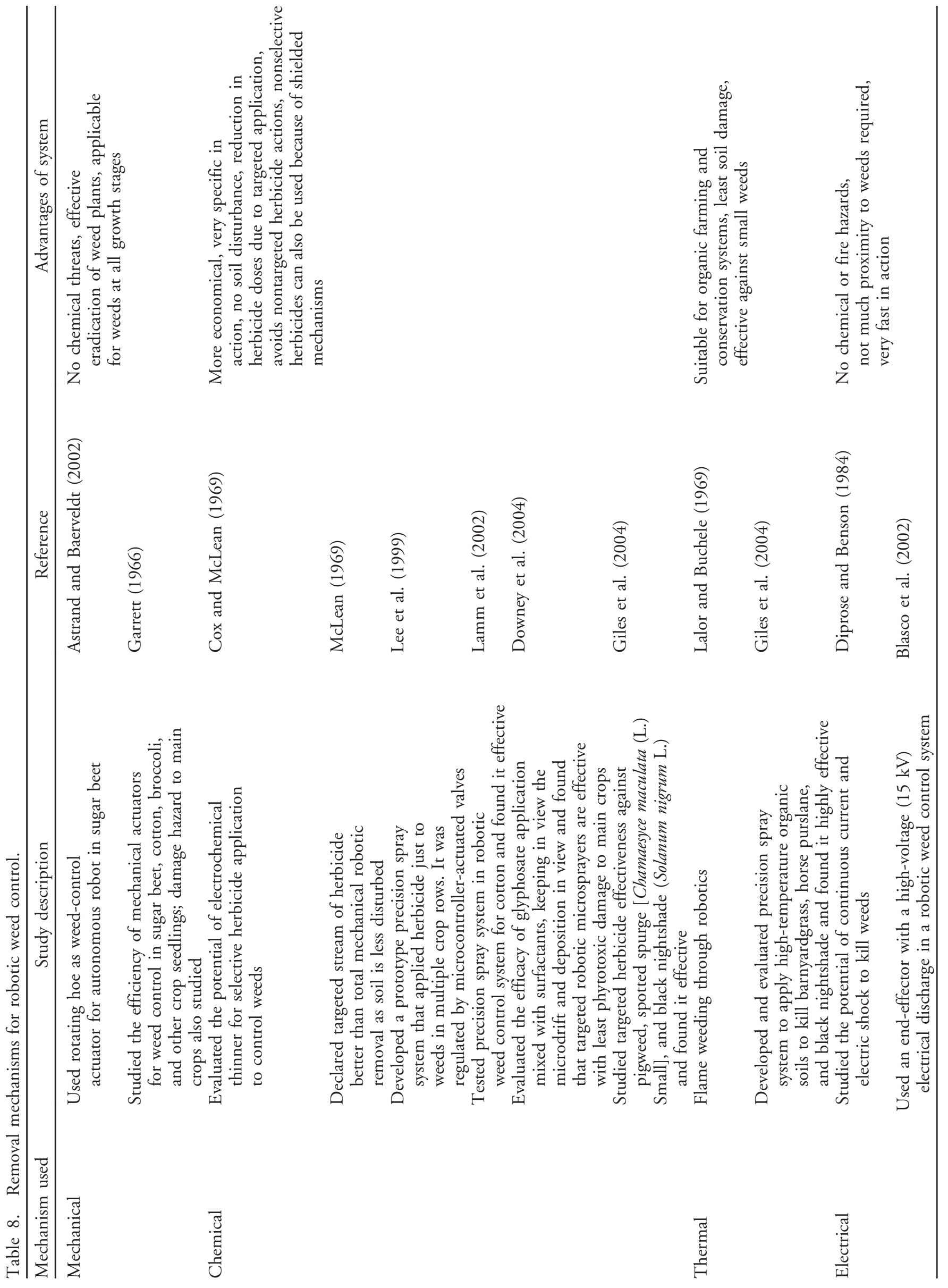

740 - Weed Science 63, October-December 2015 
technology, making it more suitable for precision weed management (Zhang and Kovacs 2012). The use of a UAV aided by a six-band multispectral camera was very successful for weed detection in a cornfield (Peña et al. 2013).

A successful case study on the use of UAVs for weed management in agronomic crops in Spain is worth sharing with details. Torres-Sánchez et al. (2013) directly utilized the UAV technology in sitespecific weed management. It was suggested that UAV technology can play a vital role in early-season site-specific weed management in sunflower, corn, sugar beet, and tomato (Solanum lycopersicum L.) crops (Torres-Sánchez et al. 2013). After initial expertise in technical management, UAVs can provide very useful information for precision weed management in a very short time. The availability and efficient working of UAVs in agriculture also provide opportunities to ecologists for scale-appropriate measurements of ecosystems. Anderson and Gaston (2013) reviewed the UAV technology with a special focus on their use in framing spatial ecology. It was reported that a range of UAVs is available on the basis of size, structure, spatial specifications, camera position, mobility, and flight altitude. UAVs are mainly applicable in the fields of population ecology (Sarda-Palomera et al. 2012), vegetation dynamics (Getzin et al. 2012), and ecosystem processing (Mayer et al. 2012).

Robotics. With the advancement in robotics research for agriculture, it is now possible to use them for one of the least mechanized aspect, that is, weed control (Young et al. 2014). Weed control is no longer limited to the use of manual eradication or herbicide sprays but can now include the use of targeted operations of machines. Slaughter et al. (2008) reported the use of robotics for weed management, a revolutionary development with multiple benefits.

Robotic weed management is a four-step process, involving guidance, identification, precision robotic removal, and mapping of weed species (Young 2012; Young et al. 2014). The feasibility of a robotic weedcontrol system depends upon machine vision analyses, robotic efficiency/suitability, variable rate application technology, decision support system, and strength of weed-sensing tools, directly or indirectly (Slaughter et al. 2008; Young 2012). Guidance in row crops is accomplished with real-time kinematic GPS or through machine vision. This technique enables a researcher to detect the intensification of inrow weeds and helps to frame threshold levels for applying control measures (Slaughter et al. 2008; Young 2012). Slaughter et al. (1999) used real-time color segmentation technology for guidance in direct-seeded lettuce, cotton, and tomato crops at different growth stages. Similarly, Kise et al. (2005) developed a guidance system on the basis of NIR stereovision, providing data of weeds in cereals but requiring some weed-free areas for calibration before actual guidance operation.

The machine vision directly depends upon climate conditions, farming practices, regional topographic differences, and cropping systems (Astrand and Baerveldt 2002; Slaughter et al. 2008). The bases for detection are classified as morphological features, spectral features, and visual textures. Morphological features of weed plants are considered as potential tools for machine vision detection, especially for distinction from other vegetation (Brown and Noble 2005; Søgaard 2005). Søgaard (2005) classified shepherd's purse, scentless mayweed, and wild mustard with great accuracy by using these active shape models. Plant reflectance is another successful indicator for weed detection through machine vision (Scotford and Miller 2005). Precise robotic weed removal on the basis of weed indication by guidance and detection is the next step. There might be the use of mechanical (Astrand and Baerveldt 2002), chemical (Lamm et al. 2002; Lee et al. 1999), thermal, or electrical (Blasco et al. 2002) approaches to remove weeds through robots. All the methods showed variable response regarding weed control; however, certain benefits are associated with each one (Table 8). Young et al. (2014) suggested automated weed control through robotics, a viable option for best integrated weed management in the future.

These technologies are no doubt the future of modern weed management and have a great role to play in precision agriculture. There is still a lot of research needed to optimize the technical requirements and to resolve the complex issues at the interface of weed spatial ecology and precision management.

\section{Conclusions and Future Perspective}

Weed management under changing climate and agricultural practices requires modern strategies. The nonjudicious use of chemical herbicides is causing environmental damage, health hazards, herbicide resistance in weeds, and nontarget actions. Thus, a set of alternative weed-management tools is needed under the prevailing conditions. The use of

Bajwa et al.: Nonconventional weed management • 741 
nonconventional and possibly nonchemical weedmanagement strategies discussed above in an integrated manner can help on a sustainable basis. All these methods focus on environmental protection, practical viability, compatibility for integrated programs, and ecological stability. The right choice of one or more of these strategies according to geographic, agricultural, and socioeconomic conditions may offer an impressive weed control. None of them has the potential to comprehensively replace chemical weed management; however, an integrated approach may lead to success. The diversified nature of these strategies may be very useful against invasive and resistant weeds. Further research is needed to optimize these tools for improvement in efficiency and practical suitability. In the long run, a single weed-control measure may not remain effective and, thus, integrated weed management on the basis of advanced nonconventional strategies will be a pragmatic option in modern intensive agriculture.

\section{Literature Cited}

Andersen J (1997) Experimental trials and modelling of hydrogen and propane burners for use in selective flaming. Biol Agric Hort 14:207-219

Anderson GL, Everitt JH, Richardson AJ, Escobar DE (1993) Using satellite data to map false broomweed (Ericamerria austrotexana) infestations on south Texas rangelands. Weed Technol 7:865-871

Anderson K, Gaston KJ (2013) Lightweight unmanned aerial vehicles will revolutionize spatial ecology. Front Ecol Environ 11:138-146

Andreasen C, Hansen L, Streibig JC (1999) The effect of ultraviolet radiation on the fresh weight of some weeds and crops. Weed Technol 13:554-560

Ascard J (1994) Dose-response models for flame weeding in relation to plant size and density. Weed Res 34:377-385

Ascard J (1995) Effects of flame weeding in weed species at different developmental states. Weed Res 35:397-411

Ash GJ (2010) The science, art and business of successful bioherbicides. Biol Control 52:230-240

Astrand B, Baerveldt AJ (2002) An agricultural mobile robot with vision-based perception for mechanical weed control. Auton Robots 13:21-35

Auld BA, Morin L (1995) Constraints in the development of bioherbicides. Weed Technol 9:638-652

Awan IU, Khan MA, Zareef M, Khan EA (2009) Weed management in sunflower with allelopathic water extract and reduced doses of a herbicide. Pak J Weed Sci Res 15:19-30

Azmi M, Azlan S, Yim KM, George TV, Chew SE (2012) Control of weedy rice in direct-seeded rice using the Clearfield production system in Malaysia. Pak J Weed Sci Res 18:49-53

Bajwa AA (2014) Sustainable weed management in conservation agriculture. Crop Prot 65:105-113

Bajwa AA, Ehsanullah, Anjum SA, Nafees W, Tanveer M, Saeed HS (2014) Impact of fertilizer use on weed management in conservation agriculture-a review. Pak J Agric Res 27:69-78
Bajwa AA, Khalid S, Sadia S, Nabeel M, Nafees W (2013) Influence of combinations of allelopathic water extracts of different plants on wheat and wild oat. Pak J Weed Sci Res 19:157-166

Banik P, Midya A, Sarkar BK, Ghose SS (2006) Wheat and chickpea intercropping systems in an additive series experiment: advantages and weed smothering. Eur J Agron 24:325-332

Batish DR, Arora K, Singh HP, Kohli RK (2007) Potential utilization of dried powder of Tagetes minuta as a natural herbicide for managing rice weeds. Crop Prot 26:566-571

Beckie HJ, Harker KN, Hall LM, Warwick SI, Légère A, Sikkema PH, Clayton GW, Thomas AG, Leeson G, Swartz S, Simard J (2006) A decade of herbicide-resistant crops in Canada. Can J Plant Sci 86:1243-1264

Berling J (1992) Getting weeds in hot water. A new hot water weed sprayer and soy-based oil help cut herbicide use. Farm Indus News 26:44-49

Bhadoria PBS (2011) Allelopathy: a natural way towards weed management. Am J Exp Agric 1:7-20

Bhattacharyya R, Prakash V, Kundu S, Srivastva AK, Gupta HS (2009) Soil aggregation and organic matter in a sandy clay loam soil of the Indian Himalayas under different tillage and crop regimes. Agric Ecosyst Environ 132:126-134

Blackshaw RE (2005) Nitrogen fertilizer, manure and compost effects on weed growth and competition with spring weed. Agron J 97:1612-1621

Blackshaw RE, Brandt RN (2008) Nitrogen fertilizer rate effects on weed competitiveness is species dependent. Weed Sci 56:743-747

Blackshaw RE, Larney FJ, Lindwall CW, Watson PR, Derksen DA (2001) Tillage intensity and crop rotation affect weed community dynamics in a winter wheat cropping system. Can J Plant Sci 81:805-813

Blackshaw RE, Molnar LJ, Chevalier DF, Lindwall CW (1998) Factors affecting the operation of the weed-sensing Detectspray system. Weed Sci 46:127-131

Blackshaw RE, Molnar LJ, Janzen HH (2004) Nitrogen fertilizer timing and application method affect weed growth and competition with spring wheat. Weed Sci 52:614-622

Blasco J, Aleixos N, Roger JM, Rabatel G, Molto E (2002) Robotic weed control using machine vision. Biosyst Eng 83:149-157

Bond W, Grundy AC (2001) Non-chemical weed management in organic farming systems. Weed Res 41:383-405

Borger CPD, Riethmuller GP, Michael A, David M, Abul H, Powles SB (2013) Increased carrier volume improves preemergence control of rigid ryegrass (Lolium rigidum) in zerotillage seeding systems. Weed Technol 27:649-655

Brain P, Cousens R (1990) The effect of weed distribution on predictions of yield loss. J Appl Ecol 27:735-742

Brainard DC, Henshaw B, Snapp S (2012) Hairy vetch varieties and bicultures influence cover crop services in strip-tilled sweet corn. Agron J 104:629-638

Brainard DC, Peachey RE, Haramoto ER, Luna JM, Rangarajan A (2013) Weed ecology and nonchemical management under strip-tillage: implications for Northern US vegetable cropping systems. Weed Technol 27:218-230

Brodie G, Hamilton S, Woodworth J (2007) An assessment of microwave soil pasteurization for killing seeds and weeds. Plant Prot Q 22:143-149 
Brodie G, Ryan C, Lancaster C (2011) Microwave technologies as part of an integrated weed management strategy: a review. Int J Agron DOI: 10.1155/2012/636905

Brown RB, Noble SD (2005) Site-specific weed management: sensing requirements-what do we need to see? Weed Sci 53:252-258

Carmona DM, Menalled FD, Landis DA (1999) Northern fieldcricket, Gryllus pennsylvanicus Burmeister (Orthoptera: Gryllidae): laboratory weed seed predation and within field activity-density. J Econ Entomol 92:825-829

Cathcart RJ, Swanton CJ (2003) Nitrogen management will influence threshold values of green foxtail (Setaria viridis) in corn. Weed Sci 51:975-986

Charudattan R (2001) Biological control of weeds by means of plant pathogens: significance for integrated weed management in modern agro-ecology. Biocontrol 46:229-260

Charudattan R (2005) Use of plant pathogens as bioherbicides to manage weeds in horticultural crops. Pages 208-214 in Proceedings of Florida State Horticultural Society. Lake Alfred, FL: Florida State Horticultural Society

Charudattan R, Dinoor A (2000) Biological control of weeds using plant pathogens: accomplishments and limitations. Crop Prot 19:691-695

Chauhan BS (2012) Weed ecology and weed management strategies for dry-seeded rice in Asia. Weed Technol 26:1-13

Chauhan BS (2013) Strategies to manage weedy rice in Asia. Crop Prot 48:51-56

Chauhan BS, Abugho SB (2013) Fertilizer placement affects weed growth and grain yield in dry-seeded rice (Oryza sativa L.) systems. Am J Plant Sci 4:1260-1264

Chauhan BS, Gill GS (2014) Ecologically based weed management strategies. Pages 1-11 in Chauhan BS, Mahajan G, eds. Recent Advances in Weed Management. New York: Springer

Chauhan BS, Gill GS, Preston C (2006) Tillage system effects on weed ecology, herbicide activity and persistence: a review. Aust J Exp Agric 46:1557-1570

Chauhan BS, Johnson DE (2010) The role of seed ecology in improving weed management strategies in the tropics. Adv Agron 105:221-262

Chauhan BS, Migo T, Westerman PR, Johnson DE (2010) Postdispersal predation of weed seeds in rice fields. Weed Res 50:553-560

Chauhan BS, Prabhjyot-Kaur, Mahajan G, Randhawa RK, Singh H, Kang MS (2014) Global warming and its possible impact on agriculture in India. Adv Agron 123:65-121

Chauhan BS, Singh RG, Mahajan G (2012) Ecology and management of weeds under conservation agriculture: a review. Crop Prot 38:57-65

Cheema ZA, Farooq M, Khaliq A (2013) Application of allelopathy in crop production: success story from Pakistan. Pages 113-143 in Cheema ZA, Farooq M, Wahid A, eds. Allelopathy: Current Trends and Future Applications. Berlin: Springer Verlag

Cheema ZA, Khaliq A (2000) Use of sorghum allelopathic properties to control weeds in irrigated wheat in semi-arid region of Punjab. Agric Ecosyst Environ 79:105-112

Cheema ZA, Khaliq A, Akhtar S (2001) Use of sorghum water extract as a natural weed inhibitor in spring mungbean. Int J Agric Biol 3:515-518

Cheema ZA, Khaliq A, Saeed S (2004) Weed control in maize (Zea mays L.) through sorghum allelopathy. J Sustain Agric 23:73-86
Cheema ZA, Khaliq A, Tariq M (2002) Evaluation of concentrated sorghum water extract alone and in combination with reduced rates of three pre-emergence herbicides for weed control in cotton (Gossypium hirsutum L.). Int J Agric Biol 4:549-552

Chhokar RS, Sharma RK, Jat GR, Pundir AK, Gathala MK (2007) Effect of tillage and herbicides on weeds and productivity of wheat under rice-wheat growing system. Crop Prot 26:1689-1696

Christensen S, Heisel T, Walter A, Graglia E (2003) A decision algorithm for patch spraying. Weed Res 43:276-284

Christensen S, Søgaard HT, Kudsk P, Nørremark M, Lund I, Nadimi ES, Jørgensen R (2009) Site-specific weed control technologies. Weed Res 49:233-241

Clements DR, Benoit DL, Murphy SD, Swanton CJ (1996) Tillage effects on weed seed return and seed bank composition. Weed Sci 44:314-322

Cox SWR, McLean KA (1969) Electro-chemical thinning of sugar beet. J Agric Eng Res 14:332-343

Creamer NG, Dabney SM (2002) Killing cover crops mechanically: review of recent literature and assessment of new research results. Am J Altern Agric 17:32-40

Day TA, Martin G, Vogelmann TC (1993) Penetration of UV-B radiation in foliage: evidence that the epidermis behaves as a non-uniform filter. Plant Cell Environ 16:735-741

DeVay J, Stapleton J, Elmore C (1991) Soil solarization. FAO Plant Production and Protection Paper 109. Rome: FAO.

Dill GM, CaJacob CA, Padgette SR (2008) Glyphosate-resistant crops: adoption, use and future considerations. Pest Manag Sci 64:326-331

Diprose MF, Benson FA (1984) Electrical methods of killing plants. J Agric Eng Res 29:197-209

DiTomaso JM (1995) Approaches for improving crop competitiveness through the manipulation of fertilization strategies. Weed Sci 43:491-497

Donald WW (1990) Primary tillage for foxtail barley (Hordeum jubatum) control. Weed Technol 4:318-321

Downey D, Giles DK, Slaughter DC (2004) Pulsed jet microspray applications for high spatial resolution of deposition on biological targets. Atomizat Sprays 14:93-109

Duerinckx K, Mouazen AM, Anthonis J, Ramon H (2005) Effects of spring-tine settings and operational conditions on the mechanical performance of a weed harrow tine. Biosyst Eng 91:21-34

Duke SO, Powles SB (2009) Glyphosate-resistant crops and weeds: now and in the future. AgBioFor 12:346-357

Evans SP, Knezevic SZ, Shapiro C, Lindquist JL (2003) Nitrogen level affects critical period for weed control in corn. Weed Sci 51:408-417

Everitt JH, Alaniz MA, Escobar DE, Davis MR (1992) Using remote-sensing to distinguish common (Isocoma coronopifolia) and drummond goldenweed (Isocoma drummondii). Weed Sci 40:621-628

Everitt JH, Escobar DE, Alaniz MA, Davis MR (1987) Using airborne middle-infrared $(1.45-2.0 \mu \mathrm{m})$ video imagery for distinguishing plant species and soil conditions. Remote Sens Environ 22:423-428

Everitt JH, Escobar DE, Villarreal R, Alaniz MA, Davis MR (1993) Canopy light reflectance and remote-sensing of Shin Oak (Querrcus havardii) and associated vegetation (Isocoma drummondii). Weed Sci 41:291-297

Farooq M, Bajwa AA, Cheema SA, Cheema ZA (2013) Application of allelopathy in crop production. Int J Agric Biol 15:1367-1378 
Farooq M, Jabran K, Cheema ZA, Wahid A, Siddique KHM (2011) The role of allelopathy in agricultural pest management. Pest Manag Sci 67:493-506

Fragasso M, Iannucci A, Papa R (2013) Durum wheat and allelopathy: toward wheat breeding for natural weed management. Front Plant Sci 4:368-375

Franke AC, Singh S, McRoberts N, Nehra AS, Godara S, Malik RK, Marshall G (2007) Phalaris minor seedbank studies: longevity, seedling emergence and seed production as affected by tillage regime. Weed Res 47:73-83

Freckleton RP, Stephens PA (2009) Predictive models of weed population dynamics. Weed Res 49:225-232

Garrett RE (1966) Device designed for synchronous thinning of plants. Agric Eng 47:652-653

Gealy DR, Mitten DH, Rutger JN (2003) Gene flow between red rice (Oryza sativa) and herbicide-resistant rice ( $O$. sativa): implications for weed management. Weed Technol 17: 627-645

Gerhards R, Christensen S (2003) Real-time weed detection, decision making and patch spraying in maize, sugar beet, winter wheat and winter barley. Weed Res 43:385-392

Getzin S, Wiegand K, Schöning I (2012) Assessing biodiversity in forests using very high-resolution images and unmanned aerial vehicles. Methods Ecol Evol 3:397-404

Ghosheh HZ (2005) Constraints in implementing biological weed control: a review. Weed Biol Manag 5:83-92

Gianessi LP (2005) Economic and herbicide use impacts of glyphosate-resistant crops. Pest Manag Sci 61:241-245

Giles DK, Downey D, Slaughter DC, Brevis-Acuna JC, Lanini WT (2004) Herbicide micro-dosing for weed control in field grown processing tomatoes. Appl Eng Agric 20:735-743

Gill KS, Arshad MA (1995) Weed flora in the early growth period of spring crops under conventional, reduced, and zero tillage systems on a clay soil in northern Alberta, Canada. Soil Till Res 33:65-79

Givens WA, Shaw DR, Kruger GR, Johnson WG, Weller SC, Young BG, Wilson RG, Owen MDK, Jordan D (2009) Survey of tillage trends following the adoption of glyphosateresistant crops. Weed Technol 23:150-155

Green JM (2012) The benefits of herbicide-resistant crops. Pest Manag Sci 68:1323-1331

Guza AE, Renner KA, Laboski C, Davis AS (2008) Effect of early spring fertilizer nitrogen on weed emergence and growth. Weed Sci 56:714-721

Haan RL, Wyse DL, Ehike NJ, Maxwell BD, Putnam DH (1994) Simulation of spring seeded smother plant for weed control in corn. Weed Sci 42:35-43

Haidar MA, Sidahmed MM (2000) Soil solarization and chicken manure for the control of Orobanche crenata and other weeds in Lebanon. Crop Prot 19:169-173

Hallett SG (2005) Where are the bioherbicides? Weed Sci 53:404-415

Hanks JE, Beck JL (1998) Sensor-controlled hooded sprayer for row crops. Weed Technol 12:308-314

Hansson D, Ascard J (2002) Influence of developmental stage and time of assessment on hot water weed control. Weed Res 42:307-316

Haramoto ER, Brainard DC (2012) Strip tillage and oat cover crops affect soil moisture and $\mathrm{N}$ mineralization patterns in cabbage. HortScience 47:1596-1602

Heap I (2014) Herbicide resistant weeds. Pages 281-301 in Pimentel D, Peshin R, eds. Integrated Pest Management. Dordrecht, The Netherlands: Springer
Heggenstaller AH, Menalled FD, Liebman M, Westerman PR (2006) Seasonal patterns in post-dispersal seed predation of Abutilon theophrasti and Setaria faberi in three-cropping systems. J Appl Ecol 43:999-1010

Hestir EL, Khanna S, Andrew ME, Santos MJ, Viers JH, Greenberg JA, Rajapakse SS, Ustin SL (2008) Identification of invasive vegetation using hyperspectral remote sensing in the California Delta ecosystem. Remote Sens Environ 112:4034-4047

Hoagland RE (1996) Chemical interactions with bioherbicides to improve efficacy. Weed Technol 10:651-674

Hoagland RE, Weaver MA, Boyette CD (2007) Myrothecium verrucaria fungus: a bioherbicide and strategies to reduce its non-target risks. Allelopathy J 19:179-192

Horowitz J, Regev Y, Herzlinger G (1983) Solarization for weed control. Weed Sci 31:170-179

Iqbal J, Cheema ZA, An M (2007) Intercropping of field crops in cotton for the management of purple nutsedge (Cyperus rotundus L.). Plant Soil 300:163-171

Iqbal J, Cheema ZA, Mushtaq MN (2009) Allelopathic crop water extracts reduce the herbicide dose for weed control in cotton (Gossypium hirsutum). Int J Agric Biol 11:360-366

Jabran K, Cheema ZA, Farooq M, Hussain M (2010) Lower doses of pendimethalin mixed with allelopathic crop water extracts for weed management in canola (Brassica napus). Int J Agric Biol 12:335-340

Jamil M, Cheema ZA, Mushtaq MN, Farooq M, Cheema MA (2009) Alternative control of wild oat and canary grass in wheat fields by allelopathic plant water extracts. Agron Sustain Dev 29:475-482

Jensen LB, Courtois B, Olofsdotter M (2008) Quantitative trait loci analysis of allelopathy in rice. Crop Sci 48:1459-1469

Khaliq A, Matloob A, Irshad MS, Tanveer A, Zamir MSI (2010) Organic weed management in maize through integration of allelopathic crop residues. Pak J Weed Sci Res 16:409-420

Kise M, Zhang Q, Rovira Mais F (2005) A stereovision-based crop row detection method for tractor-automated guidance. Biosyst Eng 90:357-367

Knežević S, Datta A, Stepanovic S, Bruening C, Neilson B, Gogos G (2011) Weed control with flaming and cultivation in corn. Phytopathology 101:81-92

Knežević S, Ulloa S (2007) Potential new tool for weed control in organically grown agronomic crops. J Agric Sci Belg 52:95-104

Kobayashi H, Miura S, Oyanagi A (2004) Effects of winter barley as a cover crop on the weed vegetation in a no-tillage soybean. Weed Biol Manag 4:195-205

Kyser GB, DiTomaso JM (2002) Instability in a grassland community after the control of yellow starthistle (Centaurea solstitialis) with prescribed burning. Weed Sci 50:648-657

Lalor WF, Buchele WF (1969) Field experiments with an aircurtain flame weeder. Agric Eng 50:358-359

Lamb DW, Brown RB (2001) Precision agriculture: remotesensing and mapping of weeds in crops. J Agric Eng Res 78:117-125

Lamb DW, Weedon M (1998) Evaluating the accuracy of mapping weeds in fallow fields using airborne digital imaging Panicum efusum in oilseed rape stubble. Weed Res 38:443-451

Lamb DW, Weedon MM, Rew LJ (1999) Evaluating the accuracy of mapping weeds in seedling crops using airborne digital imaging. Avena spp. in seedling triticale ( $\mathrm{X}$ triticosecale). Weed Res 39:481-492 
Lamm RD, Slaughter DC, Giles DK (2002) Precision weed control system for cotton. Trans ASAE 45:231-238

Lass LW, Callihan RH (1997) The effect of phenological stage on the detectability of yellow hawkweed (Heiracium pratense) and oxeye daisy (Chrysanthemum leucanthemum) with remote multispectral digital imagery. Weed Technol $11: 248-256$

Lass LW, Carson HW, Callihan RH (1996) Detection of yellow starthistle (Centaurea solstitialis) and common St John's wort (Hypericum perforatum) with multi-spectral digital imagery. Weed Technol 10:466-474

Lass LW, Prather TS, Glenn NF, Weber KT, Mundt JT, Pettingill J (2005) A review of remote sensing of invasive weeds and example of the early detection of spotted knapweed (Centaurea maculosa) and babysbreath (Gypsophila paniculata) with a hyperspectral sensor. Weed Sci 53:242-251

Lee WS, Slaughter DC, Giles DK (1999) Robotic weed control system for tomatoes. Precis Agric 1:95-113

Lindsey LE, Darryl D, Warncke KS, Wesley JE (2013) Fertilizer and population affect nitrogen assimilation of common lambsquarters (Chenopodium album) and redroot pigweed (Amaranthus retroflexus). Weed Sci 61:131-135

Lins RD, Colquhoun JB, Mallory-Smith C (2006) Investigation of wheat as a trap crop for control of Orobanche minor. Weed Res 46:313-318

López-Granados F (2011) Weed detection for site-specific weed management: mapping and real-time approaches. Weed Res 51:1-11

Major J, Steiner C, Ditommaso A, Falcão NP, Lehmann J (2005) Weed composition and cover after three years of soil fertility management in the central Brazilian Amazon: compost, fertilizer, manure and charcoal applications. Weed Biol Manag 5:69-76

Mathiassen SK, Bak T, Christensen S, Kudsk P (2006) The effect of laser treatment as a weed control method. Biosyst Eng 95:497-505

Mauchline AL, Watson SJ, Brown VK, Froud-Williams RJ (2005) Post-dispersal seed predation of non-target weeds in arable crops. Weed Res 45:157-164

Mauromicale G, Lo Monaco A, Longo AMJ, Restuccia A (2005) Soil solarization, a nonchemical method to control branched broomrape (Orobanche ramosa) and improve the yield of greenhouse tomato. Weed Sci 53:877-883

Mayer S, Sandvik A, Jonassen MO, Reuder J (2012) Atmospheric profiling with the UAS SUMO: a new perspective for the evaluation of fine-scale atmospheric models. Meteorol Atmos Phys 116:15-26

McConnachie AJ, de Wit MP, Hill MP, Byrne MJ (2003) Economic evaluation of the successful biological control of Azollafiliculoides in South Africa. Biol Control 28:25-32

McLean KA (1969) Chemical thinning of sugar beet. J Agric Eng Res 14:147-153

Medlin CR, Shaw DR (2000) Economic comparison of broadcast and site-specific herbicide applications in nontransgenic and glyphosate-tolerant Glycine max. Weed Sci 48:653-661

Medlin CR, Shaw DR, Gerard PD, LaMastus FE (2000) Using remote sensing to detect weed infestations in Glycine max. Weed Sci 48:393-398

Meiss H, Le Lagadec L, Munier-Jolain N, Waldhardt R, Petit S (2010) Weed seed predation increases with vegetation cover in perennial forage crops. Agric Ecosyst Environ 138:10-16
Melander B (1998) Interaction between soil cultivation in darkness, flaming, and brush weeding when used for in-row weed control in vegetables. Biol Agric Hort 16:1-14

Memon RA, Khalid S, Mallah A, Mirbahar AA (2011) Use of GPS and GIS technology in surveying and mapping of wheat and cotton weeds in Khairpur district, Sindh, Pakistan. Pak J Bot 43:1873-1878

Menalled F, Smith R, Dauer J, Fox T (2007) Impact of agricultural management on carabid communities and weed seed predation. Agric Ecosyst Environ 118:49-54

Menges RM, Nixon PR, Richardson AJ (1985) Light reflectance and remote-sensing of weeds in agronomic and horticultural crops. Weed Sci 33:569-581

Mesbah AO, Miller SD (1999) Fertilizer placement affects jointed goatgrass (Aegilops cylindrica) competition in winter wheat (Triticum aestivum L.). Weed Technol 13:374-377

Mohammaddoust-e-Chamanadad HR, Tulikor AM, Baghestani MA (2006) Effect of long term fertilizer application and crop rotation on the infestation of fields weeds. Pak J Weed Sci Res 12:221-234

Mohler CL, Frisch JC, Pleasant JM (1997) Evaluation of mechanical weed management programs for corn (Zea mays). Weed Technol 11:123-131

Mortensen DA, Egan JF, Maxwell BD, Ryan MR, Smith RG (2012) Navigating a critical juncture for sustainable weed management. BioScience 62:75-84

Murphy SD, Clements DR, Belaoussoff S, Kevan PG, Swanton CJ (2006) Promotion of weed species diversity and reduction of weed seedbanks with conservation tillage and crop rotation. Weed Sci 54:69-77

Myers MW, Curran WS, Van Gessel MJ, Majek BA, Mortensen DA, Calvin DD, Karsten HD, Roth GW (2005) Effect of soil disturbance on annual weed emergence in the Northeastern United States. Weed Technol 19:274-282

Nagabhushana GG, Worsham AD, Yenish JP (2001) Allelopathic cover crops to reduce herbicide use in sustainable agricultural systems. Allelopathy J 8:133-146

Naseem M, Aslam M, Ansar M, Azhar M (2010) Allelopathic effects of sunflower water extract on weed control and wheat productivity. Pak J Weed Sci Res 15:107-116

Nawaz A, Farooq M, Cheema SA, Cheema ZA (2014) Role of allelopathy in weed management. Pages 39-61 in Chauhan BS, Mahajan G, eds. Recent Advances in Weed Management. New York: Springer

Obert JC, Ridley WP, Schneider RW, Riordan SG, Nemeth MA, Trujillo WA, Breeze ML, Sorbet R, Astwood JD (2004) The composition of grain and forage from glyphosate tolerant wheat MON 71800 is equivalent to that of conventional wheat (Triticum aestivum L.). J Agric Food Chem 52:1375-1384

Owen MDK, Zelaya I (2005) Herbicide-resistant crops and weed resistance to herbicides. Pest Manag Sci 61:301-311

Ozpinar S (2006) Effects of tillage systems on weed population and economics for winter wheat production under the Mediterranean dryland conditions. Soil Till Res 87:1-8

Parish S (1990) A review of non-chemical weed control techniques. Biol Agric Hort 7:117-137

Patzoldt WL, Tranel PJ, Alexander AL, Schmizer PR (2001) A common ragweed population resistant to cloransulam-methyl. Weed Sci 49:485-490

Peachey RE, Pinkerton JN, Ivors KL, Miller ML, Moore LW (2001) Effect of soil solarization, cover crops, and metham on field emergence and survival of buried annual bluegrass (Poa annua) seeds. Weed Technol 15:81-88 
Peachey RE, William RD, Mallory-Smith C (2006) Effect of spring tillage sequence on summer annual weeds in vegetable row crop. Weed Technol 20:204-214

Peña JM, Torres-Sánchez J, de Castro AI, Kelly M, LópezGranados F (2013) Weed mapping in early-season maize fields using object-based analysis of unmanned aerial vehicle (UAV) images. PLoS ONE 8:e77151.

Peters RD, Sturz AV, Carter MR, Sanderson JB (2003) Developing disease-suppressive soils through crop rotation and tillage management practices. Soil Till Res 72:181-192

Price JC (1994) How unique are spectral signatures? Remote Sens Environ 49:181-186

Primicerio J, Di Gennaro SF, Fiorillo E, Genesio L, Lugato E, Matese A, Vaccari FP (2012) A flexible unmanned aerial vehicle for precision agriculture. Precis Agric 13:517-523

Rask AM, Kristoffersen P (2007) A review of non-chemical weed control on hard surfaces. Weed Res 47:370-380

Rask AM, Kristoffersen P, Andreasen C (2012) Controlling grass weeds on hard surfaces: effect of time intervals between flame treatments. Weed Technol 26:83-88

Rehman A, Cheema ZA, Khaliq A, Arshad M, Mohsan S (2010) Application of sorghum, sunflower and rice water extract combinations helps in reducing herbicide dose for weed management in rice. Int J Agric Biol 12:901-906

Rew LJ, Cousens RD (2001) Spatial distribution of weeds in arable crops: are current sampling and analytical methods appropriate? Weed Res 41:1-18

Ruf-Pachta EK, Rule DM, Dille JA (2013) Corn and Palmer amaranth (Amaranthus palmeri) interactions with nitrogen in dryland and irrigated environments. Weed Sci 61:249258

Sadia S, Khalid S, Qureshi R, Bajwa AA (2013) Tagetes minuta L., A useful underutilized plant of family Asteraceae: a review. Pak J Weed Sci Res 19:179-189

Samarajeewa KBDP, Horiuchi T, Oba S (2006) Finger millet (Eleucine corocana L. Gaertn.) as a cover crop on weed control, growth and yield of soybean under different tillage systems. Soil Till Res 90:93-99

Sarda-Palomera F, Bota G, Vinolo C, Pallaares O, Sazatornil V, Brotons L, Gomariz S, Sarda F (2012) Fine-scale bird monitoring from light unmanned aircraft systems. Int J Avian Sci 154:177-183

Sartorato I, Zanin G, Baldoin C, De Zanche C (2006) Observations on the potential of microwaves for weed control. Weed Res 46:1-9

Scheepens PC, Müller-Schärer H, Kempenaar C (2001) Opportunities for biological weed control in Europe. Biol Control 46:127-138

Scotford IM, Miller PCH (2005) Applications of spectral reflectance techniques in Northern European cereal production: a review. Biosyst Eng 90:235-250

Shirtliffe SJ, Entz MH (2005) Chaff collection reduces seed dispersal of wild oat (Avena fatua) by a combine harvester. Weed Sci 53:465-470

Singh HP, Batish DR, Kohli RK (2003) Allelopathic interactions and allelochemicals: new possibilities for sustainable weed management. Crit Rev Plant Sci 22:239-311

Singh S (2007) Role of management practices on control of isoproturon-resistant littleseed canarygrass (Phalaris minor) in India. Weed Technol 21:339-346

Singh S (2014) Sustainable weed management in cotton. Har J Agron 30:1-14
Singh S, Punia SS, Singh A, Brar AP (2012) Weed control efficacy of trifluralin in cotton in N-W. India. Har J Agron 28:1-10

Slaughter DC, Chen P, Curley RG (1999) Vision guided precision cultivation. Prec Agric 1:199-216

Slaughter DC, Giles DK, Downey D (2008) Autonomous robotic weed control systems: a review. Comp Elec Agric 61:63-78

Søgaard HT (2005) Weed classification by active shape models. Biosyst Eng 91:271-281

Stafford JV (2000) Implementing precision agriculture in the 21st century. J Agric Eng Res 76:267-275

Stigliani L, Resina C (1993) SELOMA — expert system for weed management in herbicide-intensive crops. Weed Technol 7:550-559

Sweeney AE, Renner KA, Laboski C, Davis A (2008) Effect of fertilizer nitrogen on weed emergence and growth. Weed Sci 56:714-721

Tarkalson DD, Bjorneberg DL, Moore A (2012) Effects of tillage system and nitrogen supply on sugarbeet production. J Sugar Beet Res 49:79-102

Thorp KR, Tian LF (2004) A review on remote sensing of weeds in agriculture. Prec Agric 5:477-508

Toler JE, Murdock EC, Camberato JJ (2004) Starter fertilizer effects on cotton development and weed interference. J Cotton Sci 8:33-41

Torres-Sánchez J, López-Granados F, De Castro AI, PeñaBarragán JM (2013) Configuration and specifications of an unmanned aerial vehicle (UAV) for early site specific weed management. PLoS ONE 8:e58210

Wallace RW, Bellinder RR (1992) Alternative tillage and herbicide options for successful weed control in vegetables. Hort Sci 27:745-749

Walsh M, Newman P, Powles SB (2013) Targeting weed seeds in-crop: a new weed control paradigm for global agriculture. Weed Technol 27:431-436

Walsh MJ, Harrington RB, Powles SB (2012) Harrington seed destructor: a new nonchemical weed control tool for global grain crops. Crop Sci 52:1343-1347

Walsh MJ, Newman P (2007) Burning narrow windrows for weed seed destruction. Field Crops Res 104:24-40

Walsh MJ, Powles SB (2007) Management strategies for herbicide resistant weed populations in Australian dryland crop production systems. Weed Technol 21:332-338

Wazir I, Sadiq M, Baloch MS, Awan IU, Khan EA, Shah IH, Nadim MA, Khakwani AA, Bakhsh I (2011) Application of bio-herbicide alternatives for chemical weed control in rice. Pak J Weed Sci Res 17:245-252

Weston LA, Duke SO (2003) Weed and crop allelopathy. Crit Rev Plant Sci 22:367-389

White SS, Renner KA, Menalled FD, Landis DA (2007) Feeding preferences of weed seed predators and effect on weed emergence. Weed Sci 55:606-612

Wiles LJ, King RP, Schweizer EE, Lybecker DW, Swinton SM (1996) GWM: general weed management model. Agric Syst 50:355-376

Worthington M, Reberg-Horton SC (2013) Breeding cereal crops for enhanced weed suppression: optimizing allelopathy and competitive ability. J Chem Ecol 39:213-231

Wu H, Pratley J, Lemerle D, Haig T (2000) Laboratory screening for allelopathic potential ofwheat (Triticum aestivum) accessions against annual ryegrass (Lolium rigidum). Aust J Agric Res 51:259-266 
Wu H, Pratley J, Ma W, Haig T (2003) Quantitative trait loci and molecular markers associated with wheat allelopathy. Theoret Appl Genet 107:1477-1481

Xiang H, Tian L (2011) Development of a low-cost agricultural remote sensing system based on an autonomous unmanned aerial vehicle (UAV). Biosyst Eng 108:174-190

Yin L, Cai Z, Zhong W (2005) Changes in weed composition of winter wheat crops due to long-term fertilization. Agric Ecosyst Environ 107:181-186

Young SL (2012) True integrated weed management. Weed Res 52:107-111

Young SL, Meyer GE, Woldt WE (2014) Future directions for automated weed management in precision agriculture. Pages 249-259 in Young SL, Pierce FJ, eds. Automation: The
Future of Weed Control in Cropping Systems. Dordrecht, The Netherlands: Springer

Zhang C, Kovacs J (2012) The application of small unmanned aerial systems for precision agriculture: a review. Prec Agric 13:693-712

Zhang L, Li D, Tong Q, Zheng L (1998) Study of the spectral mixture model of soil and vegetation in PoYang Lake area, China. Int J Remote Sens 19:2077-2084

Zimdahl, RL, ed (2013) Fundamentals of Weed Science Waltham, MA: Academic Press. Pp 295-344

Received April 18, 2015, and accepted June 16, 2015.

Associate Editor for this paper: William Vencill, University of Georgia. 